\title{
Changes in soil properties in the soil profile after mining and reclamation in an opencast coal mine on the Loess Plateau, China
}

\author{
Xiaoyang Liu ${ }^{\mathrm{a}}$, Zhongke Bai ${ }^{\mathrm{a}, \mathrm{b}, *}$, Wei Zhou, ${ }^{\mathrm{a}, \mathrm{b}}$, Yingui Cao ${ }^{\mathrm{a}, \mathrm{b}}$, Gengjie Zhang ${ }^{\mathrm{a}, \mathrm{c}}$ \\ ${ }^{a}$ School of Land Science and Technology, China University of Geosciences (Beijing), \\ Beijing 100083, PR China \\ ${ }^{\mathrm{b}}$ Key Laboratory of Land Consolidation and Rehabilitation, Ministry of Land and \\ Resources, Beijing 100035, PR China \\ ${ }^{c}$ Engineering Research Center of Science and Technology of Land and Resources, \\ Yunnan Agricultural University, Kunming 650201, PR China
}

Keywords: reclaimed mine soil; opencast coal mine; soil properties; soil profile.

* Corresponding author. Tel.: +86 10 82322182; fax: +86 1082321807.

E-mail addresses: liuxiaoyangsd@163.com (X.Y. Liu), Baizk@cugb.edu.cn (Z.K. Bai), zhouw@cugb.edu.cn (W. Zhou), caoyingui1982@126.com (Y.G. Cao), Zhanggengjie1983@163.com (G.J. Zhang). 
Abstract: Surface mining involves drastic disturbances to regional ecosystem and soil properties. Recovery of soil physicochemical characteristics is essential for successful restoration of the landscape and the soil itself after mining. To identify the changes in the soil profile after mining and reclamation, we studied the soils of the largest opencast coal mine in China, Pingshuo, located in the Loess Plateau. Soil samples representing three different land use types and six different reclamation times were collected in the soil profiles $(0-100 \mathrm{~cm})$ in 2012 and were analyzed for field capacity, bulk density, $\mathrm{pH}$, soil organic matter (SOM), N, P, K, available P, and available K. Results showed that most reclaimed mine soil properties (including bulk density, $\mathrm{pH}, \mathrm{P}, \mathrm{K}$, available $\mathrm{P}$ and available K) increased in comparison with those of the natural soils, whereas SOM and $\mathrm{N}$ decreased after mining and reclamation, especially in the topsoil $(0-40 \mathrm{~cm})$. Trend lines of $\mathrm{P}$ and available $\mathrm{K}$ in the reclaimed mine soils and natural soils were similar tested by Anova. Trend lines of $\mathrm{P}$ in the natural soils, and $\mathrm{pH}, \mathrm{P}$ and $\mathrm{K}$ in the reclaimed mine soils were relatively stable and showed no difference in the soil profile $(\mathrm{P}<0.05)$. Soil properties and their trend lines in forest land were more similar to natural soils than were cultivated land and grass land in deeper $(60-100 \mathrm{~cm})$ soil layers. Reclamation time (time that has passed after reclamation was finished) was positively associated with $\mathrm{SOM}, \mathrm{N}, \mathrm{P}$, and available $\mathrm{P}$ in cultivated land; $\mathrm{pH}$ decreased with the increase of reclamation time in forest land but $\mathrm{N}$ showed the opposite trend; $\mathrm{pH}$ and $\mathrm{P}$ were positively correlated with reclamation time but $\mathrm{K}$ and available $\mathrm{K}$ showed negative relationships with reclamation time in grassland. Bulk density vs. field capacity and 
available K vs. $\mathrm{pH}$ showed significant correlations in the soil profile $(0-100 \mathrm{~cm})$ $(\mathrm{P}<0.05)$. Significant correlations were also observed for available $\mathrm{K}$ vs. bulk density in the topsoil layer $(0-30 \mathrm{~cm})$ and bottom layer (below $60 \mathrm{~cm})(\mathrm{P}<0.05) . \mathrm{P}$ and $\mathrm{pH}$ showed positively significant correlation in the subsoil layer $(30-60 \mathrm{~cm})$ and bottom layer (below $60 \mathrm{~cm})(\mathrm{P}<0.05)$. Most of heavy metals (As, $\mathrm{Cd}, \mathrm{Cr}, \mathrm{Cu}, \mathrm{Pb}$ and $\mathrm{Hg}$ ) of cultivated land exceeded their corresponding background values in Shanxi province, where our sites were located. However, compared with Chinese soil guidelines (Grade II values) (GB15618-1995), heavy metals were all below the threshold values.

\section{Introduction}

In 2015, China produced 3750 million tons of coal, more than any other country in the world. Coal mining has made great contributions to Chinese economic developments. However, it inevitably brings serious environmental and land problems (Bai et al., 2006; Topp et al., 2010). For example, it eliminates plants, removes soil and overburden by excavation, reshapes landforms, and disrupts surface and subsurface hydrologic regimes (Herath et al., 2009; Shrestha and Lal, 2011), making coal mining one of the most notable forms of human-caused ecosystem degradation. Reclamation is an effective way to improve soil quality in mining areas (Tripathi et al., 2016). Successful reclamation can be evaluated in many ways, but soil quality is among the most important parts of restoring functional ecosystems after mining. Soil is the basis of vegetation restoration in post-mining lands, and determines the direction of land use after reclamation. Therefore, knowledge about soil dynamics during reclamation and 
recovery is particularly significant to guide future ecological restoration (Dutta and Agrawal, 2003; Courtney et al., 2009).

Physicochemical characteristics are the main indicators of mine soil quality (Yao et al., 2013; Mukhopadhyay et al., 2014; Masto et al., 2015; Mukhopadhyay et al., 2016). The influences of reclamation activities on mine soils have also been widely reported (Nyamadzawo et al., 2008; Juwarkar et al., 2010; Krümmelbein and Raab, 2012). However, few if any studies have monitored changes of reclaimed mine soil properties throughout the soil profile, particularly among different land use types and time since reclamation.

In this study, we focused on nine physicochemical properties of reclaimed mine soils in the soil profile $(0-100 \mathrm{~cm}$ depth) at the Pingshuo opencast coal mine, located on the Loess Plateau of China. The main objectives of our study were to: (1) compare the differences in soil properties between reclaimed mine soils, natural soils, and unreclaimed mine soils in the soil profile $(0-100 \mathrm{~cm})$; (2) analyze the influences of time since land reclamation (reclamation time) and land use types on soil properties; and (3) identify the relationships between soil properties in various soil layers of the profile $(0-100 \mathrm{~cm})$.

\section{Materials and methods}

\subsection{Study area}

The research was conducted in the opencast coal mine of Loess Plateau-Pingshuo, which is located in Shuozhou, northern Shanxi province of China (Fig. 1). Owing to 
lying in the border regions of Shanxi, Shaanxi and Inner Mongolia provinces in the eastern Loess Plateau, this district is also called the "black triangle". This region has the typical temperate arid to semi-arid continental monsoon climate, with the average annual temperature of $4.8-7.8^{\circ} \mathrm{C}$ and average annual precipitation of $428.2-449.0 \mathrm{~mm}$. The geomorphic type of the mining area is loess low hill area and the zonal vegetation is steppe. The zonal soil is chestnut soil and loessial soil, characterized by low content of organic matter. Ecosystem resistance ability here is poor and belongs to the typical fragile eco-environmental zone in the Loess Plateau. The Pingshuo mining area includes three large opencast mines (Anjialing, Antaibao, and Donglutian) and three underground coal mines (No.1, No.2, and No.3). The total area is approximately $160 \mathrm{~km}^{2}$. The reclamation types mainly include cultivated land, forest land and grassland (Table 1). The cultivated land in the reclaimed area had been used for agricultural production before coal mining commenced in 1986; during mining operations the cultivated land was destroyed, then gradually reclaimed as cultivated land starting in 1990.

2.2 Soil sampling and analysis

We chose eight mine soil sample sites from the dumps of Antaibao in a chronosequence of 2 years, 12 years, 14 years, 15 years, 18 years, and 22 years post-reclamation. Eight sample sites from natural sites and one sample site from unreclaimed dumps in or near the mining area were also chosen as references for comparative study (Table 1). To reduce the effects of inherent variations in soil properties, criteria of similar topography and geologic strata were applied to choose the 
sample sites. Considering the limited soil depth, 10 samples from ten depths per site $(0-10 \mathrm{~cm}, 10-20 \mathrm{~cm}, 20-30 \mathrm{~cm}, 30-40 \mathrm{~cm}, 40-50 \mathrm{~cm}, 50-60 \mathrm{~cm}, 60-70 \mathrm{~cm}, 70-80 \mathrm{~cm}$, 80-90 cm, and 90-100 cm) were collected both in the reclaimed mine soil and natural soil; 4 samples from four depths per site $(0-10 \mathrm{~cm}, 10-20 \mathrm{~cm}, 20-30 \mathrm{~cm}$, and $30-40 \mathrm{~cm})$ were collected in unreclaimed mine soil using a shovel during July 2012 (Fig. 2). Since the unreclaimed mine soils were all loess parent material and were just dumped a few months ago, the spatial distributions of soil properties were relatively uniform. One soil profile in the typical region can represent the whole condition of unclaimed mine soil properties to a great extent.

Before physicochemical analyses, all samples were air-dried, crushed, and sieved through a 2-mm polyethylene sieve. All samples were analyzed for field capacity, bulk density, $\mathrm{pH}$, soil organic matter (SOM), N, P, K, available P, and available K. Field capacity was analyzed using the Wilcox method (Salter and Williams, 1965). Bulk density was analyzed with the cutting ring method (Zeng et al., 2014). pH was measured using a pH meter at a ratio of soil/water of 1:2.5 (Mc Lean, 1982). SOM concentration was analyzed by potassium dichromate oxidation titration (Liu et al., 1996). N concentration was measured by the semi-micro Kjeldahl method (Fawcett, 1954). P concentration was measured by the $\mathrm{NaOH}$ melting molybdenum antimony colorimetric method (Zhen et al., 2015). K concentration was measured by the filtered solution via flame emission spectrometry (Schneider and Mollier, 2016). Available P was measured using the Olsen method (Olsen and Sommers, 1982). Available K was measured using 
flame photometric (Motsara and Roy, 2008).

\section{Table 1}

Basic description of the sample sites.

\begin{tabular}{|c|c|c|c|c|c|}
\hline & No. & Location & $\begin{array}{c}\text { Land use } \\
\text { types }\end{array}$ & $\begin{array}{l}\text { Reclamation } \\
\text { time (year) }\end{array}$ & Vegetation \\
\hline \multirow{8}{*}{ Natural soils } & $\mathrm{O} 1$ & North expansion of ATB West Dump & \multirow{5}{*}{$\begin{array}{c}\text { Cultivated } \\
\text { land }\end{array}$} & -- & \multirow{2}{*}{ Fagopyrum esculentum } \\
\hline & $\mathrm{O} 2$ & Shidong village of Shuozhou city & & -- & \\
\hline & $\mathrm{O} 3$ & Dayinzhuang village of Shuozhou city & & -- & \\
\hline & $\mathrm{O} 4$ & Shiyu village of Shuozhou city & & -- & Maize \\
\hline & O5 & Quanwuying village of Shuozhou city & & -- & \\
\hline & O6 & Northeast expansion of ATB West Dump & \multirow{2}{*}{ Forest land } & -- & \multirow{2}{*}{ Populus simonii } \\
\hline & $\mathrm{O} 7$ & Sishengdian village of Shuozhou city & & -- & \\
\hline & O8 & Shizhuang village of Shuozhou city & Grassland & -- & Alfalfa \\
\hline \multirow{8}{*}{$\begin{array}{l}\text { Reclaimed } \\
\text { mine soils }\end{array}$} & $\mathrm{R} 1$ & West Dump of ATB & \multirow{3}{*}{$\begin{array}{c}\text { Cultivated } \\
\text { land }\end{array}$} & 18 & Ricinus communis \\
\hline & $\mathrm{R} 2$ & Fynoncion of ATR Whet Dump & & 15 & \multirow{2}{*}{ Solanum tuberosum } \\
\hline & R3 & Expansion or AI D west Dump & & 2 & \\
\hline & $\mathrm{R} 4$ & South Dumn of ATR & \multirow{3}{*}{ Forest land } & 22 & \multirow{3}{*}{ Populus simonii } \\
\hline & R5 & S & & 18 & \\
\hline & R6 & West Dump of ATB & & 12 & \\
\hline & R7 & Expansion of ATB West Dump & \multirow{2}{*}{ Grassland } & 18 & \multirow{2}{*}{ Alfalfa } \\
\hline & R8 & South Dump of ATB & & 14 & \\
\hline $\begin{array}{l}\text { Unreclaimed } \\
\text { mine soil }\end{array}$ & $\mathrm{U} 1$ & Inner Dump of ATB & Wasteland & -- & -- \\
\hline
\end{tabular}

\subsection{Statistical analysis}

Means and standard errors were calculated for the soil characteristics for both reclaimed mine soils and natural soils. Trend lines generated by multiple linear regressions were used to simulate the general trend of soil properties changing in the profile. The general shapes of trend lines were compared by overlaying pictures. One-way ANOVA was also used to test the differences of trend lines and the means of soil characteristics. Therefore, to identify the relationships between soil properties in various soil layers of the profile $(0-100 \mathrm{~cm})$, we divided reclaimed mine soils into three layers: surface $(0-30 \mathrm{~cm})$, middle $(30-60 \mathrm{~cm})$, and bottom $(60-100 \mathrm{~cm})$. A Pearson's 
correlation matrix among soil characteristics for the reclaimed mine soils in three soil layers was constructed. All statistical analyses were performed using SPSS 19.0 (SPSS Inc. Chicago, USA).

\section{Results}

3.1 Physicochemical properties of the natural soils in the soil profile.

The physicochemical characteristics of the natural soils and their changes with the increase of soil depth within the profile $(0-100 \mathrm{~cm})$, based on trend lines and analysis of variance, are given in Fig. 3.

Trend lines of field capacity and $\mathrm{P}$ in the natural soil profiles were similar, decreasing first and then increasing with soil depth. However, the differences in these physicochemical characteristics between different soil layers in the full profile depth of $0-100 \mathrm{~cm}$ were not significant $(\mathrm{P}<0.05)$. Bulk density increased from $1.28 \mathrm{~g} \mathrm{~cm}^{-3}$ in $0-10 \mathrm{~cm}$ to $1.41 \mathrm{~g} \mathrm{~cm}^{-3}$ in $10-20 \mathrm{~cm}(\mathrm{P}<0.05)$ and kept relatively stable in the deeper depth $(20-100 \mathrm{~cm}) . \mathrm{pH}$ was alkaline throughout and its value in $10-40 \mathrm{~cm}$ was significantly higher than that in $80-40 \mathrm{~cm}$. Concentrations of SOM and $\mathrm{N}$ both decreased with the increase of soil depth $(0-100 \mathrm{~cm})$ and showed similar change patterns. The rates of decreases of SOM and $\mathrm{N}$ were pronounced in the topsoil (0-30 $\mathrm{cm}$ ), as shown by the ANOVA and in Fig. 3. The trend line of available P was consistent with that of available $\mathrm{K}$, both forming an "S" shape in the graph of the profile. Concentrations of available $\mathrm{P}$ and available $\mathrm{K}$ at the depth of $0-10 \mathrm{~cm}$ were $4.95 \mathrm{mg}$ $\mathrm{kg}^{-1}$ and $104.34 \mathrm{mg} \mathrm{kg}^{-1}$, respectively, both significantly higher than their values at the 
other soil depths $(\mathrm{P}<0.05)$. The change trend of $\mathrm{K}$ varied from those of the other soil characteristics. The range of $\mathrm{K}$ was $15.05-18.58 \mathrm{~g} \mathrm{~kg}^{-1}$. $\mathrm{K}$ concentration in the soil layer of 90-100 cm was significantly higher than that in the soil layer of $0-10 \mathrm{~cm}$. In the soil layer of $20-80 \mathrm{~cm}$, its trend line was relatively straight, indicating $\mathrm{K}$ concentration was relatively stable in this soil layer.

3.2 Physicochemical properties of the reclaimed mine soils in the profile

After mining and reclamation, physicochemical characteristics of soils varied considerably from those of the natural soils. The concentrations and trend lines of the soil properties in the soil profile are given in Fig. 4.

The ranges of field capacity, bulk density, $\mathrm{P}, \mathrm{K}$, available $\mathrm{P}$, and available $\mathrm{K}$ in the reclaimed mine soils were larger than those in the natural soils; that is, these characteristics were more variable in the reclaimed mine soils. Field capacity varied between $16.4-18.15 \%$ in natural soils and between $15.33-19.14 \%$ in reclaimed soils; bulk density increased significantly after reclamation $(\mathrm{P}=0.001)$ and varied between $1.28-1.41 \mathrm{~g} \mathrm{~cm}^{-3}$ in natural soils and between $1.29-1.55 \mathrm{~g} \mathrm{~cm}^{-3}$ in reclaimed soils. Concentrations of $\mathrm{P}$ and $\mathrm{K}\left(0.41-0.54 \mathrm{~g} \mathrm{~kg}^{-1}\right.$ and $\left.15.79-19.67 \mathrm{~g} \mathrm{~kg}^{-1}\right)$ in reclaimed mine soils were significantly higher than those in natural soil $(\mathrm{P}=0.02, \mathrm{P}=2.15 \mathrm{E}-5)$. Similarly, ranges of available $\mathrm{P}$ and available $\mathrm{K}$ expanded in reclaimed mine soils compared with natural soils. For available $\mathrm{P}$ and available $\mathrm{K}$, the increase was especially pronounced: available P rose from $1.61-4.95 \mathrm{mg} \mathrm{kg}^{-1}$ to $6.98-13.2 \mathrm{mg} \mathrm{kg}^{-1}$ and available $\mathrm{K}$ rose from $56.4-104.34 \mathrm{mg} \mathrm{kg}^{-1}$ to $68.71-127.46 \mathrm{mg} \mathrm{kg}^{-1}$. These results indicate that activities of 
coal mining and reclamation have a great effect these properties.

Some soil characteristics had stable or narrowed concentration range in the reclaimed soils compared with natural soils. Both $\mathrm{pH}$ and $\mathrm{N}$ had similar ranges whether in natural or reclaimed mine soils, but $\mathrm{pH}$ was more alkaline in reclaimed mine soils (8.18-8.31) compared with that in natural soils $(8-8.21)(\mathrm{P}=6.85 \mathrm{E}-12)$ and $\mathrm{N}$ concentration decreased from $0.3-0.56 \mathrm{~g} \mathrm{~kg}^{-1}$ in natural soils to $0.21-0.5 \mathrm{~g} \mathrm{~kg}^{-1}$ in the reclaimed mine soils $(\mathrm{P}=1.66 \mathrm{E}-4)$. $\mathrm{SOM}$ concentration of the reclaimed mine soils deceased significantly $(\mathrm{P}=0.04)$ in the topsoils $(0-40 \mathrm{~cm})$, and its range narrowed down by about half in from that of the natural soils, meaning that topsoil SOM concentration had not recovered to the natural level after reclamation.

Trend lines of most soil characteristics within the profile differed from those of the natural soils. The downward trend of SOM and $\mathrm{N}$ with the increase of soil depth in natural sites was disturbed after mining and reclamation. Trend lines of field capacity, $\mathrm{P}$, and available $\mathrm{P}$ of the reclaimed soils changed in the shape and fluctuated more significantly than the natural soils. Changes of field capacity were not significant in the natural soils, but in reclaimed mine soils, field capacity in the soil layer of $0-10 \mathrm{~cm}$ was higher than that in $40-50 \mathrm{~cm}$ and $70-100 \mathrm{~cm}$ soil depth. P concentration of natural soils and reclaimed mine soils showed no difference in the whole soil profile $(0-100 \mathrm{~cm})$. Available P had a difference between $10-30 \mathrm{~cm}$ and $90-100 \mathrm{~cm}$ soil layers for the reclaimed mine soils and had a difference between $0-10 \mathrm{~cm}$ and $10-100 \mathrm{~cm}$ soil layers for the natural soils. There was less variation in $\mathrm{pH}$ in the reclaimed soils than in the 
natural soils. These changes in trend lines for most soil characteristics were further evidence of the great effects exerted by mining and reclamation on soil properties.

3.3 Physicochemical properties of reclaimed mine soils with different reclamation times and different land use types

The properties of reclaimed mine soils with different reclamation times and different land use types were compared with those of the natural soils and unreclaimed mine soils (Fig. 5, Fig. 6, and Fig. 7).

In the cultivated post-reclamation soil (Fig. 5), field capacity and bulk density of 15- and 18-year reclaimed mine soils were close to the levels of the natural soils in the 0-10 $\mathrm{cm}$ and $50-80 \mathrm{~cm}$ soil layers. Similarly, soil became looser with the increase of soil depth within $0-40 \mathrm{~cm}$, but the change trend in field capacity was just the opposite. Trend lines of $\mathrm{pH}$ varied considerably among different chronosequence sites. At 0-20 $\mathrm{cm}, \mathrm{pH}$ of the natural soils was higher than that of the mine soils, and at deeper layers the 15-year reclaimed mine soils had a higher $\mathrm{pH}$ than the natural soils.

Similar to the cultivated land, field capacity in topsoil $(0-10 \mathrm{~cm})$ of grassland exceeded the natural level, but in deeper layers, the field capacities of the reclaimed mine soils were below that of the natural soil. $\mathrm{pH}$ was positively correlated with reclamation time and the 18 -year reclaimed mine soil was more alkaline than the natural soil.

In the post-reclamation forest land, $\mathrm{P}$ was similar in the 12 - and 18 -year reclaimed soils, with both values higher than in the 22 -year reclaimed soil. $\mathrm{K}$ also showed little 
change between 12- and 18-year reclaimed soils, but rose in the 22-year reclaimed soil.

SOM in $0-10 \mathrm{~cm}$ soil depth and $\mathrm{N}$ in the overall soil profile increased with reclamation time, with values in the order: natural soil $>18$-year reclaimed mine soil $>$ 14-year reclaimed soil $>$ unreclaimed mine soil. P showed a positive correlation with reclamation time. Mine soils at 14 years (throughout the profile) and 18 years (at $0-10$ $\mathrm{cm})$ post-reclamation had lower $\mathrm{P}$ concentration than the natural soil, but $\mathrm{P}$ concentration in 18-year reclaimed mine soil deeper than $10 \mathrm{~cm}$ exceeded the natural level. $\mathrm{K}$, available $\mathrm{P}$, and available $\mathrm{K}$ of the reclaimed mine soils were all higher than those of the natural soil overall, and $\mathrm{K}$ and available $\mathrm{K}$ decreased with the increase of reclamation time.

3.4 Physicochemical properties of unreclaimed mine soil profiles

The physicochemical characteristics of the unreclaimed mine soils in the soil profile $(0-100 \mathrm{~cm})$ are given in Fig. 8. Values of bulk density, available P, and available $\mathrm{K}$ in the unreclaimed soils were significantly higher than the natural soils $(\mathrm{P}=0.023$, 0.003 and 0.001 , respectively) and reclaimed soils $(\mathrm{P}=0.021,0.047$, and 0.012$)$. Bulk density concentration range rose from $1.28-1.41 \mathrm{~g} \mathrm{~cm}^{-3}$ and $1.29-1.53 \mathrm{~g} \mathrm{~cm}^{-3}$ in the natural soils and reclaimed mine soils, respectively, to $1.69-1.83 \mathrm{~g} \mathrm{~cm}^{-3}$ in the unreclaimed mine soils $(\mathrm{P}=8.71 \mathrm{E}-5)$, meaning that reclamation can effectively loosen mine soils. The increase trend was more significant for available $\mathrm{P}$ and available $\mathrm{K}$, with available P changing from $1.61-4.95 \mathrm{mg} \mathrm{kg}^{-1}$ and $6.89-9.3 \mathrm{mg} \mathrm{kg}^{-1}$ in the natural soils and reclaimed mine soils, respectively, to $10.81-13.56 \mathrm{mg} \mathrm{kg}^{-1}$ in unreclaimed mine 
soils, and available $\mathrm{K}$ from $57.91-104.34 \mathrm{mg} \mathrm{kg}^{-1}$ and $68.71-127.46 \mathrm{mg} \mathrm{kg}^{-1}$ to $155.74-178.58 \mathrm{mg} \mathrm{kg}^{-1}$.

On the contrary, SOM concentration and $\mathrm{N}$ concentration of unreclaimed mine soils were lower than in natural soils and reclaimed mine soils at the soil depth of 0-40 $\mathrm{cm}$, indicating that SOM and $\mathrm{N}$ easily escaped unreclaimed mine soils, owing to the absence of vegetation coverage. The variation range at $0-40 \mathrm{~cm}$ was extended for field capacity and $\mathrm{K}$ in comparison with natural soils and reclaimed mine soils. Meanwhile, the $0-10 \mathrm{~cm}$ soil layer showed the maximum values for these properties, reaching $20.45 \%$ and $25.36 \mathrm{~g} \mathrm{~kg}^{-1}$ for field capacity and $\mathrm{K}$, respectively. Unreclaimed mine soils had consistently alkaline $\mathrm{pH}$. Its variation range was $8.21-8.28$, between that of the natural soils and the reclaimed mine soils.

3.5 Relationship among soil properties in different soil layer

Relationship among soil properties is shown in Table 2. In 0-30 cm layer, there were five significant correlations between pairs of soil properties. Bulk density was negatively correlated with both field capacity and available $\mathrm{K} . \mathrm{pH}$ and available $\mathrm{K}$ were negatively correlated with one another. SOM had significant correlations with $\mathrm{N}\left(\mathrm{R}^{2}=\right.$ $0.629)$ and available $K\left(R^{2}=0.383\right)$. In the middle soil layer of $30-60 \mathrm{~cm}$, more significant correlations were found among the soil properties. Bulk density showed significant correlations with field capacity, N, and K. Significant correlations were also observed for $\mathrm{pH}$ vs. $\mathrm{P}, \mathrm{pH}$ vs. $\mathrm{K}$, $\mathrm{pH}$ vs. available $\mathrm{K}$, $\mathrm{P}$ vs. $\mathrm{K}$, and $\mathrm{K}$ vs. available $\mathrm{K}$. As with soils within $0-10 \mathrm{~cm}$, bulk density also showed negative correlations with bulk 
density and available $\mathrm{K}$ in the $60-100 \mathrm{~cm}$ soil depth. pH was significantly correlated with $\mathrm{N}$ and available $\mathrm{K}$. P showed a negative correlation with available $\mathrm{K}$.

\section{Table 2}

Relationship among soil properties for the reclaimed mine soils in three different soil layers: 0-30 cm, 30-60 $\mathrm{cm}$ and $60-100 \mathrm{~cm}$.

\begin{tabular}{|c|c|c|c|c|c|c|c|c|c|c|}
\hline Soil depth & Soil properties & FC & $\mathrm{BD}$ & $\mathrm{pH}$ & SOM & $\mathrm{N}$ & $\mathrm{P}$ & $\mathrm{K}$ & AP & AK \\
\hline \multirow{9}{*}{$0-30 \mathrm{~cm}$} & $\mathrm{FC}$ & 1 & & & & & & & & \\
\hline & $\mathrm{BD}$ & $-0.633 * *$ & 1 & & & & & & & \\
\hline & $\mathrm{pH}$ & -0.102 & 0.374 & 1 & & & & & & \\
\hline & SOM & 0.082 & -0.073 & 0.048 & 1 & & & & & \\
\hline & $\mathrm{N}$ & -0.040 & -0.025 & 0.328 & $0.629 * *$ & 1 & & & & \\
\hline & $\mathrm{P}$ & 0.031 & 0.32 & -0.217 & -0.066 & 0.004 & 1 & & & \\
\hline & $\mathrm{K}$ & -0.119 & -0.316 & -0.350 & -0.091 & -0.363 & -0.039 & 1 & & \\
\hline & $\mathrm{AP}$ & 0.029 & -0.019 & -0.084 & -0.027 & 0.100 & 0.197 & 0.196 & 1 & \\
\hline & $\mathrm{AK}$ & 0.192 & $-0.519 * *$ & $-0.459 *$ & $0.383 * *$ & 0.163 & -0.314 & 0.004 & -0.126 & 1 \\
\hline \multirow{9}{*}{$30-60 \mathrm{~cm}$} & $\mathrm{FC}$ & 1 & & & & & & & & \\
\hline & $\mathrm{BD}$ & $-0.433 *$ & 1 & & & & & & & \\
\hline & $\mathrm{pH}$ & -0.182 & 0.198 & 1 & & & & & & \\
\hline & SOM & -0.027 & 0.099 & 0.046 & 1 & & & & & \\
\hline & $\mathrm{N}$ & -0.284 & $0.564 * *$ & 0.374 & -0.009 & 1 & & & & \\
\hline & $\mathrm{P}$ & 0.041 & $0.442^{*}$ & $0.439 *$ & -0.067 & 0.287 & 1 & & & \\
\hline & $\mathrm{K}$ & 0.136 & $-0.593^{* *}$ & $-0.658 * *$ & -0.03 & -0.341 & $-0.741 * *$ & 1 & & \\
\hline & AP & 0.088 & -0.041 & 0.064 & -0.154 & 0 & 0.146 & -0.119 & 1 & \\
\hline & $\mathrm{AK}$ & -0.338 & 0.068 & $-0.464^{*}$ & -0.058 & 0.37 & -0.298 & $0.496 *$ & -0.215 & 1 \\
\hline \multirow{9}{*}{$60-100 \mathrm{~cm}$} & $\mathrm{FC}$ & 1 & & & & & & & & \\
\hline & $\mathrm{BD}$ & $-0.534 * *$ & 1 & & & & & & & \\
\hline & $\mathrm{pH}$ & -0.079 & 0.280 & 1 & & & & & & \\
\hline & SOM & 0.031 & 0.194 & 0.257 & 1 & & & & & \\
\hline & $\mathrm{N}$ & 0.230 & -0.083 & 0.299 & 0.266 & 1 & & & & \\
\hline & $\mathrm{P}$ & 0.205 & 0.317 & $0.483^{*}$ & 0.214 & 0.249 & 1 & & & \\
\hline & $\mathrm{K}$ & -0.146 & -0.315 & -0.129 & -0.094 & 0.112 & -0.128 & 1 & & \\
\hline & $\mathrm{AP}$ & -0.172 & 0.116 & 0.110 & 0.079 & -0.021 & 0.036 & 0.224 & 1 & \\
\hline & AK & -0.020 & $-0.506^{* *} *$ & $\mathbf{- 0 . 4 2 0} *$ & -0.327 & -0.089 & $\mathbf{- 0 . 7 0 3} * *$ & 0.329 & -0.013 & 1 \\
\hline
\end{tabular}

** Correlation is significant at 0.01 level; * Correlation is significant at 0.05 level. FC means field capacity; BD means bulk density; AP means available P; AK means available $\mathrm{K}$. 
3.6 Heavy metal concentrations of reclaimed mine soils and natural soils for cultivated land

Heavy metal concentrations of reclaimed mine soils and natural soils for cultivated land are shown in Table 3. Most of the heavy metals exceed their corresponding background values in Shanxi province, where our sites were located. However, compared with Chinese soil guidelines (Grade II values) proposed by the State Environmental Protection Administration of China (GB15618-1995), which can be used as the threshold values for protecting human health and ensuring agricultural production, the levels all six heavy metals were below the threshold values.

\section{Table 3}

Heavy metal concentrations in reclaimed mine soils and natural soils of cultivated land. Soil samples $(0-30 \mathrm{~cm})$ were collected in the study area during August 2013.

\begin{tabular}{cccccccc}
\hline & Number & \multicolumn{6}{c}{ Concentrations of heavy metal elements/(mg. $\left.\mathrm{kg}^{-1}\right)$} \\
\cline { 3 - 8 } & of sample & $\mathrm{As}$ & $\mathrm{Cd}$ & $\mathrm{Cr}$ & $\mathrm{Cu}$ & $\mathrm{Pb}$ & $\mathrm{Hg}$ \\
\hline Reclaimed mine soils & 5 & $9.19-12.04$ & $0.12-0.14$ & $64.10-76.00$ & $21.52-24.72$ & $20.27-22.06$ & $0.02-0.03$ \\
Natural soils & 19 & $8.62-13.07$ & $0.10-0.16$ & $58.70-88.70$ & $16.27-25.07$ & $17.79-25.09$ & $0.02-0.51$ \\
Shanxi Background & & 7.80 & 0.112 & 53.00 & 22.50 & 13.80 & 0.017 \\
Grade II values & & 20 & 0.20 & 90 & 35 & 35 & 0.15 \\
\hline
\end{tabular}

\section{Discussion}

\subsection{Reclamation effect on soil properties}

In order to analyze reclamation effect on soil properties, we made comparisons with other literatures. The comparisons are shown in Table 4.

\section{Table 4}

Concentrations of the soil properties acquired in this study and comparisons with other selected sites.

\begin{tabular}{c|l|c|c|c}
\hline Location & Soil properties & $\begin{array}{c}\text { Concentration in this } \\
\text { study }\end{array}$ & $\begin{array}{c}\text { Concentration in the } \\
\text { reference }\end{array}$ & Reference \\
\hline $\begin{array}{c}\text { Yang coal mine, } \\
\text { China }\end{array}$ & Field capacity & $\begin{array}{c}18.86-30.82 \% \text { in } \\
\text { reclainmed mine soils }\end{array}$ & $\begin{array}{c}15.33-19.14 \% \text { in } \\
\text { reclainmed mine soils }\end{array}$ & Wang et al., 2011 \\
\hline
\end{tabular}




\begin{tabular}{|c|c|c|c|c|}
\hline $\begin{array}{l}\text { Malanzhuang } \\
\text { mine, China }\end{array}$ & & $\begin{array}{l}18.86-30.82 \% \text { in } \\
\text { reclainmed mine soils }\end{array}$ & $\begin{array}{l}10.50-16.34 \% \text { in } \\
\text { reclainmed mine soils }\end{array}$ & Li et al., 2014 \\
\hline $\begin{array}{c}\text { Kusunda opencast } \\
\text { projects, India }\end{array}$ & Bulk density & $\begin{array}{l}1.29-1.55 \mathrm{~g} \mathrm{~cm}^{-3} \text { in } \\
\text { reclainmed mine soils }\end{array}$ & $\begin{array}{l}1.47-1.67 \mathrm{~g} \mathrm{~cm}^{-3} \text { in } \\
\text { reclainmed mine soils }\end{array}$ & $\begin{array}{l}\text { Mukhopadhyay } \\
\text { and Maiti, } 2011\end{array}$ \\
\hline $\begin{array}{l}\text { Manganese spoil } \\
\text { dump, India }\end{array}$ & $\mathrm{pH}$ & $\begin{array}{l}8.18-8.31 \text { in reclainmed } \\
\text { mine soils and } 8-8.21 \text { in } \\
\text { natural soils }\end{array}$ & $\begin{array}{c}7.5 \text { in reclainmed mine } \\
\text { soils and } 6.9 \text { in natural } \\
\text { soils }\end{array}$ & $\begin{array}{c}\text { Juwarkar et } \\
\text { al.,2010 }\end{array}$ \\
\hline $\begin{array}{l}\text { Global databases } \\
\text { of soil profiles }\end{array}$ & SOM & $\begin{array}{l}\text { SOM decreased from } \\
10.69 \mathrm{~g} \mathrm{~kg}^{-1} \text { to } 2.61 \mathrm{~g} \mathrm{~kg}^{-1} \\
\text { in the profile }(0-100 \mathrm{~cm})\end{array}$ & $\begin{array}{c}\text { soil organic carbon } \\
\text { decreased from } 41(\%) \text { to } 9 \\
(\%) \text { in the profile }(0-100 \\
\mathrm{cm})\end{array}$ & $\begin{array}{l}\text { Jobbagy and } \\
\text { Jackson, } 2000\end{array}$ \\
\hline $\begin{array}{l}\text { Naya Dara } \\
\text { colliery coal } \\
\text { mine, India }\end{array}$ & $\mathrm{N}$ & $\begin{array}{l}0.3-0.56 \mathrm{~g} \mathrm{~kg}^{-1} \text { in natural } \\
\text { soils, } 0.22-0.5 \mathrm{~g} \mathrm{~kg}^{-1} \text { in } \\
\text { reclaimed mine soil and }\end{array}$ & $\begin{array}{c}954-1870 \mathrm{~kg} \mathrm{ha}^{-1} \text { in } \\
\text { reclaimed mine soils and } \\
810 \mathrm{~kg} \mathrm{ha}^{-1} \text { in unreclaimed } \\
\text { mine soils }\end{array}$ & Singh et al., 2012 \\
\hline $\begin{array}{l}\text { Eight counties of } \\
\text { eastern Ohio, } \\
\text { USA }\end{array}$ & & $\begin{array}{l}0.19-0.2 \mathrm{~g} \mathrm{~kg}^{-1} \text { in } \\
\text { unreclaimed mine soils }\end{array}$ & $\begin{array}{l}1.1-2.96 \mathrm{~g} \mathrm{~kg}^{-1} \text { in natural } \\
\text { soils } 0.54-1.1 \mathrm{~g} \mathrm{~kg}^{-1} \text { in } \\
\text { reclaimed mine soil }\end{array}$ & $\begin{array}{c}\text { Shrestha and Lal, } \\
2011\end{array}$ \\
\hline $\begin{array}{l}\text { Naya Dara } \\
\text { colliery coal } \\
\text { mine, India }\end{array}$ & $\mathrm{P}$ & $\begin{array}{c}0.42-0.54 \mathrm{~g} \mathrm{~kg}^{-1} \text { in } \\
\text { reclaimed mine soils and } \\
0.36-0.41 \mathrm{~g} \mathrm{~kg}^{-1} \text { in natural } \\
\text { soils }\end{array}$ & $\begin{array}{l}414-862 \mathrm{~kg} \mathrm{ha}^{-1} \text { in } \\
\text { reclaimed mine soils and } \\
604 \mathrm{~kg} \mathrm{ha}^{-1} \text { in natural soils }\end{array}$ & Singh et al., 2012 \\
\hline $\begin{array}{c}\text { Vishwakarma } \\
\text { opencast projects, } \\
\text { India }\end{array}$ & Available P & $\begin{array}{l}6.98-13.2 \mathrm{mg} \mathrm{kg}^{-1} \text { in } \\
\text { reclainmed mine soils }\end{array}$ & $\begin{array}{l}4.8-10.8 \mathrm{mg} \mathrm{kg}^{-1} \text { in } \\
\text { reclainmed mine soils }\end{array}$ & $\begin{array}{c}\text { Mukhopadhyay et } \\
\text { al., } 2013\end{array}$ \\
\hline
\end{tabular}

Field capacity is an important parameter in soil water research, especially in the drought-prone Loess Plateau since soil water is the restrict factor for vegetation to grow normally there. The increase in field capacity after mining and reclamation was smaller in our study than has been previously reported (Wang et al., 2011). However, Li et al. (2014) found that field capacity varied between $10.50 \%$ and $16.34 \%$ in the soil depth of 0-60 $\mathrm{cm}$ after reclamation under three different vegetation types, higher than that found in the reclaimed mine soils of our study. The different results may be due to differences in the vegetation species planted or recruited after mining. Because of the frequent movement of heavy machinery excavating and replacing topsoil material in the 
reclamation process, the reclaimed mine soils were highly compacted, leading to high bulk density (Shrestha and Lal, 2011). This is in agreement with the previous reports that bulk density of unreclaimed mine soils $\left(1.71-2.04 \mathrm{~g} \mathrm{~cm}^{-3}\right)$ was significantly higher than reclaimed mine soils $\left(1.47-1.67 \mathrm{~g} \mathrm{~cm}^{-3}\right.$ ) (Mukhopadhyay and Maiti, 2011) and increased with soil depth (Ahirwal and Maiti, 2016). pH plays an important role in ecological restoration owing to its function in moderating availability of plant nutrients. Severe soil disturbance inevitably causes changes in soil $\mathrm{pH}$, usually resulting in increased $\mathrm{pH}$ (Ganjegunte et al., 2009). The type of bedrock and carbonate-rich overburden materials promote the increase in soil $\mathrm{pH}$. Our finding that the $\mathrm{pH}$ of reclaimed mine soils was higher than that of natural soils was also reported by Juwarkar et al. (2010). Recovery of SOM in soils after reclamation is a slow process and usually takes decades to recover close to the natural level. According to Cui et al. (2012), soil organic carbon (SOC) concentration declines initially after reclamation and takes about 40 years to recover. At our site, SOM concentration in topsoil was significantly higher than in deeper layers in both the natural soils and the reclaimed mine soils, which may be attributed to the conversion from leaf litter fall to humus in the topsoil. A similar finding was also reported by Jobbagy and Jackson (2000). In general, inputs of $\mathrm{N}$ are minimal in natural ecosystems because $\mathrm{N}$ retention and efficient cycling are essential for the maintenance of ecosystem productivity (Mummey et al., 2002). Reclamation activities help to increase the proportion of soil aggregates and could reduce loss of soil nutrients ( $\mathrm{N}$ and $\mathrm{P}$ ) from tillage practices and irrigation (Bronick and Lal, 2005), and 
this may be one reason why $\mathrm{P}$ and $\mathrm{K}$ increased throughout the soil profile after reclamation. The influence of mining activity on $\mathrm{N}$ concentration was also studied by Singh et al. (2012) and Shrestha and Lal (2011), who found similar results. Concentrations of available $\mathrm{P}$ and available $\mathrm{K}$ in the reclaimed mine soils were significantly higher than those in natural soils but lower than those in the unreclaimed mine soils. The lower concentrations of available $\mathrm{P}$ and available $\mathrm{K}$ in natural soils might be attributable to the increased uptake and assimilation by plant roots in the ecosystem reconstruction progress. Available $\mathrm{P}$ concentration in the reclaimed mine soils of our sites was higher than available $\mathrm{P}$ concentration of coal mine soils after reclamation founded by Mukhopadhyay et al. (2013).

4.2 Influence of reclamation age and land use type on soil characteristics

Restoration of soil properties depends on post-reclamation land use type. Reclamation age also exerts a significant influence on soil properties due to the vegetation functional and structural changes in the process of ecological restoration (Hodkinson et al., 2003; Kumar et al., 2015). In general, SOM and N were low in mine soils, which is unfavorable for vegetation establishment and sustainable productivity (Li, 2006; Zhao et al., 2013). Both could be replenished from roots, harvest residues, and organic fertilizers (Khan et al., 2016). In our study, SOM and N were connected and positively associated with reclamation time overall, except $\mathrm{N}$ of the 15 -year reclaimed mine soils in $20-80 \mathrm{~cm}$, in the order: natural soils $>18$-year reclaimed soils $>15$-year reclaimed soils $>2$-year reclaimed soils $>$ unreclaimed mine soils. A decrease of $\mathrm{N}$ in 
mining-affected lands was also found by Ahirwal and Maiti (2016). Both P and available $\mathrm{P}$ improved significantly with reclamation and showed positive relationships with reclamation time. However, $\mathrm{K}$ and available $\mathrm{K}$ of 18 -year reclaimed mine soils were lowest among the chronosequence, and were below that of the natural soils at 20-100 $\mathrm{cm}$ for $\mathrm{K}$ and the whole profile for available K. It was notable that available K of the unreclaimed mine soil was much higher than that of the natural soils and reclaimed mining soils. This may be caused by the more uptake of available $\mathrm{K}$ by plants and crops on the natural sites and reclaimed area.

In the post-reclamation forest land, field capacity of the three chronosequence sites exceeded the natural levels in most soil layers within $0-100 \mathrm{~cm}$. This may be due to the increases in clay content, litter accumulation, and canopy cover (Maiti, 2013) and was in agreement with the earlier study (Venkatesh et al., 2011). Field capacity of the 22-year reclaimed mine soil decreased to $9.78 \%$ at $70-80 \mathrm{~cm}$ and remained below the natural level at deeper layers. Compared with reclaimed mine soils of cultivated land in the profile and natural soils in the $0-20 \mathrm{~cm}$ depth, bulk density was lower in the forest land. This may be attributed to root system development, addition of biomass, and the reduction of anthropogenic disturbance after reclamation (Thomas et al., 2000). The 22-year reclaimed and 18-year reclaimed mine soils were looser than the 12-year reclaimed mine soil at $0-30 \mathrm{~cm}$ depth, but at greater depths soils became compacted and bulk density exceeded that of the 12-year reclaimed mine soil. Overall, reclamation activity improved mine soil physical quality as reported in earlier studies (Asensio et al., 
2013; Srivastava et al., 2014). An increase in reclamation time also saw a decreased pH overall. This decrease in $\mathrm{pH}$ was probably due to the change in SOC and clay percentage after reclamation, which could extract base cations from and release protons into the soil (Van Breemen et al., 1984). The 22-year reclaimed mine soil had pH levels near and around the natural levels. The trend lines of SOM and $\mathrm{N}$ of this soil were similar to those of the natural soils, but unlike the earlier study (Banning et al., 2008), the post-reclamation accumulations of SOM and $\mathrm{N}$ were slow and their levels were lower than in the natural soils. Reclamation time was negatively correlated with $\mathrm{N}$ concentration. This might mainly attributed to the change of vegetation types along reclamation time. In the early years after reclamation, trees are sparse but shrub and annual grass grow well, and litter with rich organic nitrogen source returned to the soil and decomposed. But over reclamation time, trees dominate. Annual litter decreases whereas uptake of $\mathrm{N}$ by vegetation from soil increases, which leads to the decrease of $\mathrm{N}$ concentration in soil. It was notable that $\mathrm{P}, \mathrm{K}$, available $\mathrm{P}$, and available $\mathrm{K}$ increased after mining and reclamation. This is evidence of the important roles played by litter accumulation and root development on mine soil quality changes after reclamation.

All post-reclamation mine soils were looser than natural soil at $0-40 \mathrm{~cm}$ depths and all depths of unreclaimed mine soil, a finding consistent with that reported by Wu et al. (2016), who suggested that the types of artificial grassland used in reclamation, and their resultant root biomasses, have significant influences on the physical properties of mine soils. Compared with soils of cultivated land and forest land, SOM and N of the 
natural soil in the grass land were higher at $20-80 \mathrm{~cm}$ soil depth, which was probably owing to the important role of annual grasses in conservation and improvement of soil quality (Wang and Gong, 1998).

4.3 Relationship of soil properties for the reclaimed mine soils among various soil layers

Agricultural soil is usually divided into three layers: topsoil $(0-30 \mathrm{~cm})$, subsoil (30-60 cm), and bottom (below $60 \mathrm{~cm}$ ) (Lin et al., 2002). Topsoil is affected mainly by human activities and has abundant roots from crops, grass, and trees; subsoil is less affected by the external environment; and the bottom layer is mainly affected by the deeper wastes, such as those associated with mining.

Many other studies have also found significant relationships among various characteristics of reclaimed mine soils (Shrestha and Lal, 2011; Zhen et al., 2015; Datta et al., 2015). The lower number of significant relationships found in the surface and bottom soil layers compared with the middle soil layer was probably caused by disturbances from both contact surfaces, above and below. Reclaimed mine soils are unique in their characteristics, simultaneously disturbed by human activities in the surface layer and influenced by wastes associated with mining in the bottom layer.

\subsection{Heavy metal pollution of cultivated land}

Pollution of soil by heavy metals is among the main environmental problems that endangers human health and ecosystems (Clemente et al., 2007), and it has attracted much attention from mine eco-environmental researchers in recent years (Gomez-Ros et al., 2013; Cai et al., 2015). Mining activities are often associated with heavy metal 
pollution in cultivated land because the mining wastes are highly enriched in heavy metals. Phytotoxicity resulting from toxic metal contamination in cultivated land and crops affects the food chain and threatens human health. Therefore, it is essential to address heavy metal pollution for soils of cultivated land.Concentrations of heavy metals found at our sites were compared with those of other relevant studies. It was found that As concentration was higher than the finding in coal mine-affected agricultural soils in the northern part of Bangladesh (Bhuiyan et al., 2010), with the range of $5.66-8.25 \mathrm{mg} / \mathrm{kg}$. $\mathrm{Pb}$ and $\mathrm{Hg}$ concentrations were much lower than those in soils from the Oltu coal mine district in Turkey (Tozsin, 2014).

\section{Conclusions}

Mining and land reclamation significantly altered the physicochemical characteristics in the soil profile. Our findings suggest most reclaimed mine soil properties (bulk density, $\mathrm{pH}, \mathrm{P}, \mathrm{K}$, available $\mathrm{P}$, and available $\mathrm{K}$ ) increased after reclamation. However, SOM and $\mathrm{N}$ are not easy to recover in years, especially in the topsoil. Land use type also had significant influences on reclaimed mine soil. We found that soil properties and their trend lines in forest land were more similar to those of natural soils than to those of cultivated and grasslands in deeper soil layers (60-100 $\mathrm{cm})$.

Our findings suggest that effects of reclamation time on soil properties differed in different land use types. Reclamation time showed positive associations with SOM, N, P and available $\mathrm{P}$ in cultivated land; $\mathrm{pH}$ decreased with an increase in reclamation time, 
but $\mathrm{N}$ showed the opposite trend in forest land. In grassland, $\mathrm{pH}$ and $\mathrm{P}$ were positively correlated with reclamation time, but $\mathrm{K}$ and available $\mathrm{K}$ showed a negative relationship with reclamation time.

The significant correlated pairs of soil properties in the whole soil profile $(0-100$ $\mathrm{cm}$ ) were field capacity vs. bulk density and available K vs. pH. Available K vs. bulk density both showed a significant correlation in the surface soil layer $(0-30 \mathrm{~cm})$ and the middle soil layers $(30-60 \mathrm{~cm}) . \mathrm{P}$ vs. $\mathrm{pH}$ was significantly correlated in the middle soil layers $(30-60 \mathrm{~cm})$ and bottom soil layer $(60-100 \mathrm{~cm})$.

Most of the heavy metals exceeded their corresponding background values in Shanxi province. However, they were all below the threshold values (Grade II values) (GB15618-1995) for protecting human health and ensuring agricultural production.

\section{Acknowledgements}

This research was supported by National Science Foundation of China (41571508). We thank Xiang Ding, Jian Pan and Ming Jing for their help with the field and laboratory work. We are extremely grateful to the anonymous reviewers for their insightful comments and suggestions. 


\section{References}

Ahirwal, J., Maiti, S.K. Assessment of soil properties of different land uses generated due to surface coal mining activities in tropical Sal (Shorea robusta) forest, India. Catena, 2016,140: 155-163.

Asensio, V., Vega, F.A., Andrade, M.L., Covelo, E.F. Tree vegetation and waste amendments to improve the physical condition of copper mine soils. Chemosphere, 2013,90(2): 603-610.

Bai, Z.K., Fu, M.C., Zhao, Z.Q. On soil environmental problems in mining area. Ecology and Environment, 2006,15(5): 1122-1125.

Banning, N.C., Grant, C.D., Jones, D.L., Murphy, D.V. Recovery of soil organic matter, organic matter turnover and nitrogen cycling in a post-mining forest rehabilitation chronosequence. Soil Biology and Biochemistry, 2008,40(8): 2021-2031.

Bhuiyan, M.A.H., Parvez, L., Islam, M.A., Dampare, S.B., Suzuki, S. Heavy metal pollution of coal mine-affected agricultural soils in the northern part of Bangladesh. Journal of Hazardous Materials, 2010,173(1-3): 384-392.

Bronick, C., Lal, R. Soil structure andmanagement: a review. Geoderma, 2005,124(1): $3-22$.

Cai, L.M., Xu, Z.C., Qi, J.Y., Feng, Z.Z., Xiang, T.S. Assessment of exposure to heavy metals and health risks among residents near Tonglushan mine in Hubei, China. Chemosphere, 2015,127: 127-135.

Clemente, R., Paredes, C., Bernal, M.P. A field experiment investigating the effects of 
olive husk and cow manure on heavy metal availability in a contaminated calcareous soil from Murcia (Spain). Agriculture, ecosystems \& environment, 2007,118(1-4): 319-326.

Courtney, R., Mullen, G., Harrington, T. An evaluation of revegetation successon bauxite residue. Restoration ecology, 2009,17(3): 350-358.

Cui, J., Liu, C., Li, Z.L., Wang, L., Chen, X.F., Ye, Z.Z., Fang, C.M. Long-term changes in topsoil chemical properties under centuries of cultivation after reclamation of coastal wetlands in the Yangtze Estuary, China. Soil and Tillage Research, 2012,123: 50-60.

Datta, A., Basak, N., Chaudhari, S.K., Sharma, D.K. Soil properties and organic carbon distribution under different land uses in reclaimed sodic soils of North-West India. Geoderma Regional, 2015,4: 134-146.

Dutta, R.K., Agrawal, M. Restoration of opencast coal mine spoil by planting exotic tree species: a case study in dry tropical region. Ecological Engineering, 2003,21(2): 143-151.

Fawcett, J.K. The semi-micro Kjeldahl method for the determination of nitrogen. The Journal of medical laboratory technology, 1954,12(1): 1-22.

Ganjegunte, G.K., Wick, A.F., Stahl, P.D., Vance, G.F. Accumulation and composition of total organic carbon in reclaimed coal mine lands. Land Degradation \& Development, 2009,20(2): 156-175.

Gomez-Ros, J.M., Garcia, G., Penas, J.M. Assessment of restoration success of former 
metal mining areas after 30 years in a highly polluted Mediterranean mining area: Cartagena-La Union. Ecological engineering, 2013,57: 393-402.

Herath, D.N., Lamont, B.B., Enright, N.J., Miller, B.P. Comparison of post-mine rehabilitated and natural shrub land communities in southwestern Australia. Restoration Ecology, 2009,17(5): 577-585.

Hodkinson, I.D., Coulson, S.J., Webb, N.R. Community assembly along proglacial chronosequences in the high Arctic: vegetation and soil development in north-west Svalbard. Journal of Ecology, 2003,91(4): 651-663.

Jobbagy, E.G., Jackson, R.B. The vertical distribution of soil organic carbon and its relation to climate and vegetation. Ecological applications, 2000,10(2): 423-436.

Juwarkar, A.A., Mehrotraa, K.L., Nair, R., Wanjari, T., Singh, S.K., Chakrabarti, T. Carbon sequestration in reclaimed manganese mine land at Gumgaon, India. Environ Monit Assess, 2010,160(1-4): 457-464.

Khan, K.S., Mack, R., Castillo, X., Kaiser, M., Joergensen, R.G. Microbial biomass, fungal and bacterial residues, and their relationships to the soil organic matter C/N/P/S ratios. Geoderma, 2016,271: 115-123.

Krümmelbein, J., Raab, T. Development of soil physical parameters in agricultural reclamation after brown coal mining within the first four years. Soil and Tillage Research, 2012,125: 109-115.

Kumar, S., Maiti, S.K., Chaudhuri, S. Soil development in 2--21 years old coalmine reclaimed spoil with trees: A case study from Sonepur-Bazari opencast project, 
Raniganj Coalfield, India. Ecological Engineering, 2015,84: 311-324.

Li, M.S. Ecological restoration of mineland with particular reference to the metalliferous mine wasteland in China: A review of research and practice. Science of the total environment, 2006,357(1): 38-53.

Lin D.Y., Wang Q.B, Bai Z.K., Xie Y.H. Soil science. Beijing: China Forestry Publishing House, 2002.

Liu, G.S., Jiang, N.H., Zhang, L.D. Soil physical and chemical analysis description of soil profiles. Beijing: Standards Press of China, 1996.

Li, X.Y., Xu, X.H., Guo, J., Zhao, S., Li, Y.L. Effects of different forestation species on the substrate physicochemical properties and soil fauna in iron tailings. Acta Ecologica Sinica, 2014(20): 5746-5757.

Maiti, S.K. Ecorestoration of the Coalmine Degraded Lands. New York: Springer, 2013.

Masto, R.E., Sheik, S., Nehru, G., Selvi, V.A., George, J., Ram, L.C. Assessment of environmental soil quality around Sonepur Bazari mine of Raniganj coalfield, India. Solid Earth, 2015,6(3): 811-821.

Mc Lean, E.O. Soil pH and lime requirement, In: Page, A.L., Miller, R.H., Keeney, D.R. (Eds.), Methods of soil analysis. Part 2. Chemical and microbiological properties, 2nd Edition. Agronomy Monograph No. 9. ASA and SSSA, Madison, WI, 1982, pp. $199-224$.

Motsara, M.R., Roy, R.N. Guide to Laboratory Establishment for Plant Nutrient 
Analysis. Rome: Food and Agriculture Organization of the United Nations, 2008.

Mukhopadhyay, S., Maiti, S.K. Trace metal accumulation and natural mycorrhizal colonisation in an afforested coalmine overburden dump: a case study from India. International Journal of Mining, Reclamation and Environment, 2011,25(2): 187-207.

Mukhopadhyay, S., Maiti, S.K., Masto, R.E. Use of Reclaimed Mine Soil Index (RMSI) for screening of tree species for reclamation of coal mine degraded land. Ecological Engineering, 2013,57: 133-142.

Mukhopadhyay, S., Maiti, S.K., Masto, R.E. Development of mine soil quality index (MSQI) for evaluation of reclamation success: A chronosequence study. Ecological Engineering, 2014,71: 10-20.

Mukhopadhyay, S., Masto, R.E., Yadav, A., George, J., Ram, L.C., Shukla, S.P. Soil quality index for evaluation of reclaimed coal mine spoil. Science of The Total Environment, 2016,542, Part A: 540-550.

Mummey, D.L., Stahl, P.D., Buyer, J.S. Soil microbiological properties 20 years after surface mine reclamation: spatial analysis of reclaimed and undis-turbed sites. Soil Biology and Biochemistry, 2002,34(11): 1717-1725.

Nyamadzawo, G., Shukla, M.K., Lal, R. Spatial variability of total soil carbon and nitrogen stocks for some reclaimed minesoils of Southeastern Ohio. Land Degradation \& Development, 2008,19(3): 275-288.

Olsen, S.R., Sommers, L.E. Phosphorus. In: Miller, A.L., Keeney, D.R. (Eds.), Methods 
of Soil Analysis. American Society of Agronomy, Madison, 1982, pp. 403-427.

Salter, P.J., Williams, J.B. The influence of texture on the moisture characteristics of soils. II. Available water capacity and moisture release characteristics. Journal of Soil Science, 1965,16: 310-317.

Schneider, A., Mollier, A. Modelling of K/Ca exchange in agricultural soils. Geoderma, 2016,271: 216-224.

Shrestha, R.K., Lal, R. Changes in physical and chemical properties of soil after surface mining and reclamation. Geoderma, 2011,161(3): 168-176.

Singh, R.S., Tripathi, N., Chaulya, S.K. Ecological study of revegetated coal mine spoil of an Indian dry tropical ecosystem along an age gradient. Biodegradation, 2012,23(6): 837-849.

Srivastava, N.K., Ram, L.C., Masto, R.E. Reclamation of overburden and lowland in coal mining area with fly ash and selective plantation: A sustainable ecological approach. Ecological Engineering, 2014,71: 479-489.

Thomas, K.A., Sencindiver, J.C., Skousen, J.G., Gorman, J.M. Soil horizon development on a mountain surface mine in Southern West Virginca. Green Lands, 2000,30(3): 41-52.

Topp, W., Thelen, K., Kappes, H. Soil dumping techniques and afforestation drive ground-dwelling beetle assemblages in a 25 -year-old open-cast mining reclamation area. Ecological Engineering, 2010,36(6): 751-756.

Tozsin, G. Hazardous elements in soil and coal from the Oltu coal mine district, Turkey. 
International Journal of Coal Geology, 2014,131: 1-6.

Tripathi, N., Singh, R.S., Hills, C.D. Soil carbon development in rejuvenated Indian coal mine spoil. Ecological Engineering, 2016,90: 482-490.

Van Breemen, N., Driscoll, C.T., Mulder, J. Acidic deposition and internal proton sources in acidification of soils and waters. Nature, 1984,307(5952): 599-604.

Venkatesh, B., Lakshman, N., Purandara, B.K., Reddy, V.B. Analysis of observed soil moisture patterns under different land covers in Western Ghats, India. Journal of Hydrology, 2011,397(3): 281-294.

Wang, L.Y., Han, Y.Z., Zhang, C.L., Pei, Z.Y. Reclaimed soil properties and weathered gangue change characteristics under various vegetation types on gangue pile. Acta Ecologica Sinica, 2011(21): 6429-6441.

Wang, X.J., Gong, Z.T. Assessment and analysis of soil quality changes after eleven years of reclamation in subtropical China. Geoderma, 1998,81(3): 339-355.

Wu, G.L., Yang, Z., Cui, Z., Liu, Y., Fang, N.F., Shi, Z.H. Mixed artificial grasslands with more roots improved mine soil infiltration capacity. Journal of Hydrology, 2016,535: 54-60.

Yao, R.J., Yang, J.S., Gao, P., Zhang, J.B., Jin, W.H. Determining minimum data set for soil quality assessment of typical salt-affected farmland in the coastal reclamation area. Soil and Tillage Research, 2013,128: 137-148.

Zeng, X., Zhang, W., Cao, J., Liu, X., Shen, H., Zhao, X. Changes in soil organic carbon, nitrogen, phosphorus, and bulk density after afforestation of the 
“Beijing-Tianjin Sandstorm Source Control” program in China. Catena, 2014,118: 186-194.

Zhao, Z.Q., Shahrour, I., Bai, Z.K., Fan, W.X., Feng, L.R., Li, H.F. Soils development in opencast coal mine spoils reclaimed for 1 - 13 years in the West-Northern Loess Plateau of China. European Journal of Soil Biology, 2013,55: 40-46.

Zhen, Q., Ma, W.M., Li, M.M., He, H.H., Zhang, X.C., Wang, Y. Effects of vegetation and physicochemical properties on solute transport in reclaimed soil at an opencast coal mine site on the Loess Plateau, China. Catena, 2015,133: 403-411.

\section{Figure Captions:}

Fig. 1. Location of the study area and distribution of the soil samples.

Fig. 2. Soil profiles excavated in the field.

Fig. 3. Physicochemical properties of the natural soils in the soil profile. Letters show significant differences $(\mathrm{P}<0.05)$ among different soil layers.

Fig. 4. Physicochemical properties of the reclaimed mine soils in the profile. Means were produced using the data of all the soil samples collected from the reclaimed areas. Letters show significant differences $(\mathrm{P}<0.05)$ among different soil layers and whiskers indicate Standard Deviation.

Fig. 5. Mine soil characteristics in cultivated land.

Fig. 6. Mine soil characteristics in forest land.

Fig. 7. Mine soil characteristics in grass land. 
Fig. 8. Physicochemical properties of the unreclaimed mine soils in the profile. 

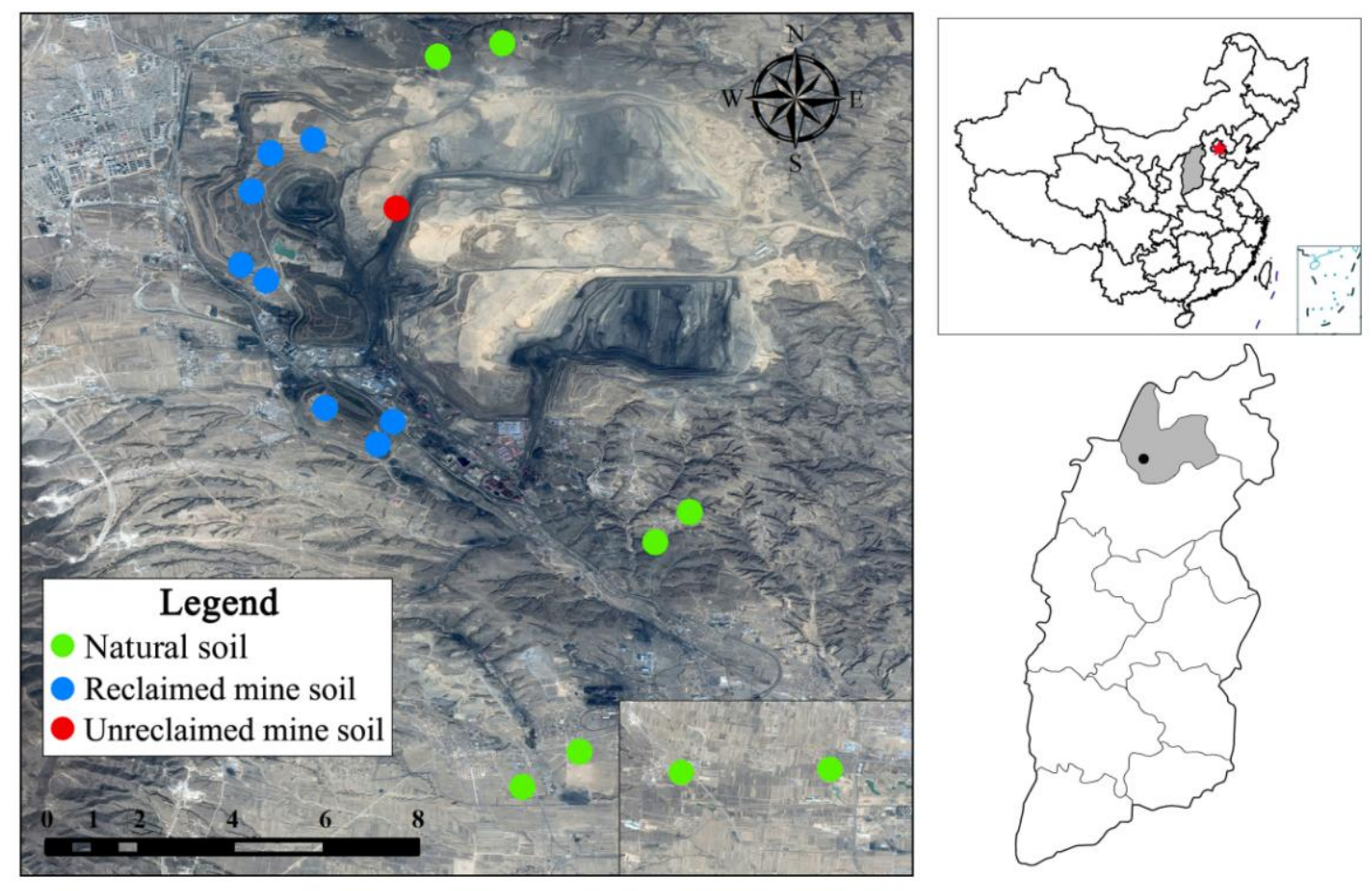


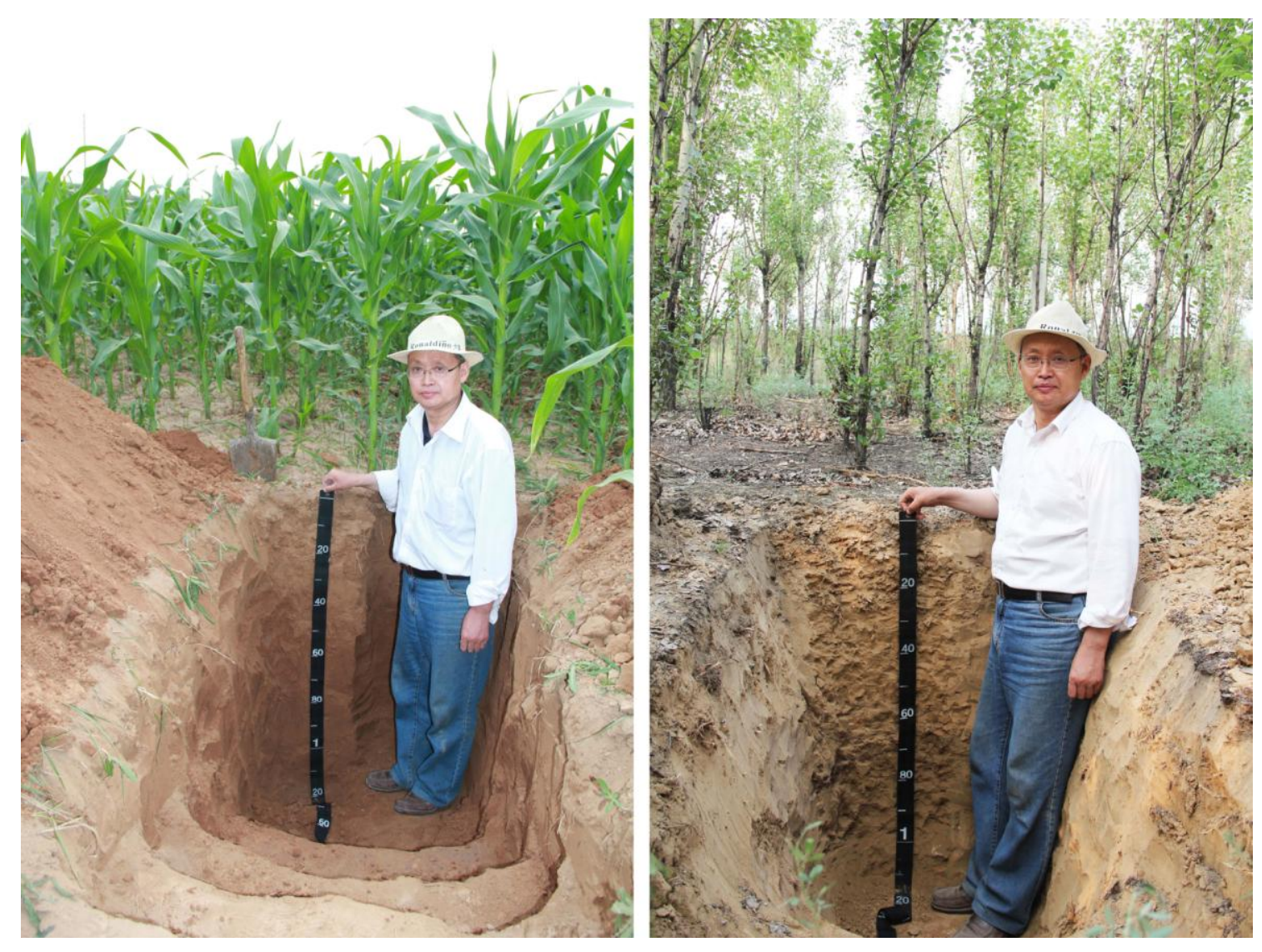


Field capacity $(\%)$

(a) $\begin{array}{llllllll}0 & 3 & 6 & 9 & 12 & 15 & 18 & 21\end{array}$
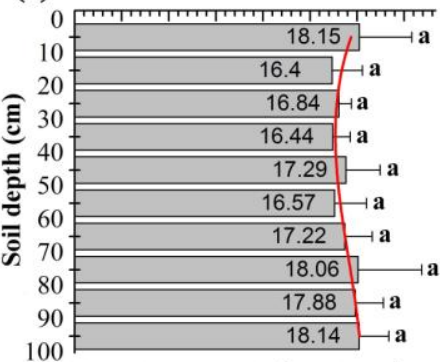

$y=18.03-0.09 x+0.17 E-2 x^{2}-8.09 E-6 x^{3}$ $\operatorname{Adj} . R^{2}=0.65$

\section{$\operatorname{SOM}\left(\mathrm{g} \mathrm{kg}^{-1}\right)$}

(d) $\begin{array}{llllllll}0 & 2 & 4 & 6 & 8 & 10 & 12 & 14\end{array}$
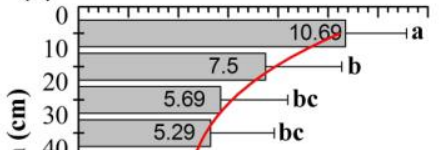

$40 t \quad 5.29$

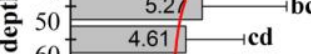

$60=3.78$ cd

$80-3.82$

$80=3.64$

2001

$y=12.14-0.36 x+0.56 E-2 x^{2}-3.04 E-5 x^{3}$ Adj. $R^{2}=0.97$

\section{$\mathrm{K}\left(\mathrm{g} \mathrm{kg}^{-1}\right)$}

$\begin{array}{llllllll}\text { (g) } & 0 & 4 & 8 & 12 & 16 & 20 & 24\end{array}$

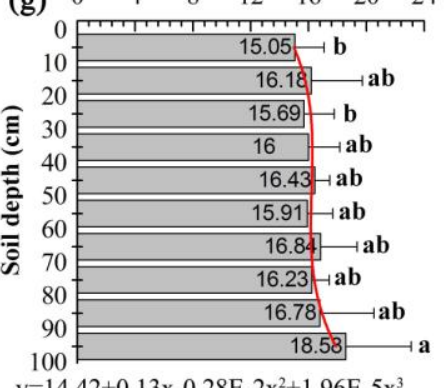

$\mathrm{y}=14.42+0.13 \mathrm{x}-0.28 \mathrm{E}-2 \mathrm{x}^{2}+1.96 \mathrm{E}-5 \mathrm{x}$ Adj. $R^{2}=0.55$
Bulk density $\left(\mathrm{g} \mathrm{cm}^{-3}\right)$

(b) $\begin{array}{lllllllll}0.0 & 0.2 & 0.4 & 0.6 & 0.8 & 1.0 & 1.2 & 1.4 & 1.6\end{array}$

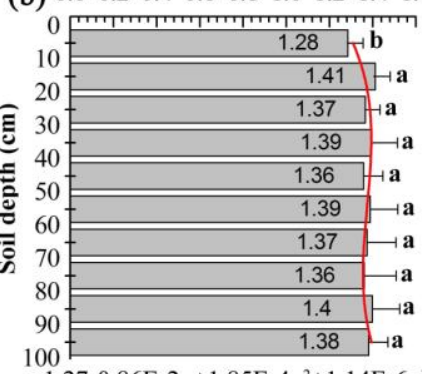

$y=1.27-0.86 \mathrm{E}-2 \mathrm{x}+1.85 \mathrm{E}-4 \mathrm{x}^{2}+1.14 \mathrm{E}-6 \mathrm{x}^{3}$ $\operatorname{Adj} . R^{2}=0.25$

$\mathrm{N}\left(\mathrm{g} \mathrm{kg}^{-1}\right)$

(e) $\begin{array}{llllllll}0.0 & 0.1 & 0.2 & 0.3 & 0.4 & 0.5 & 0.6 & 0.7\end{array}$

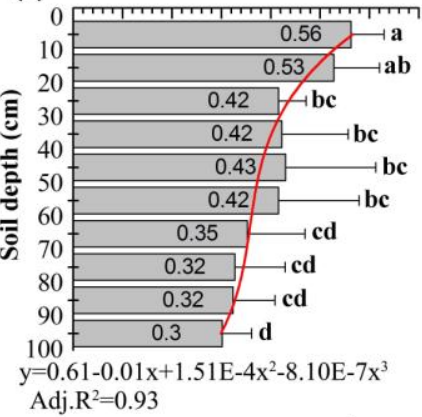

Available $\mathbf{P}$ ( $\mathrm{mg} \mathrm{kg}^{-1}$ )

(h) $\begin{array}{llllllllll}0 & 1 & 2 & 3 & 4 & 5 & 6 & 7 & 8 & 9\end{array}$

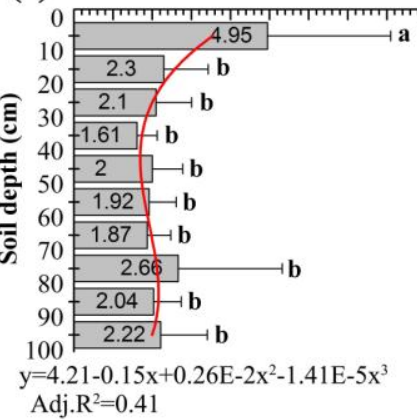

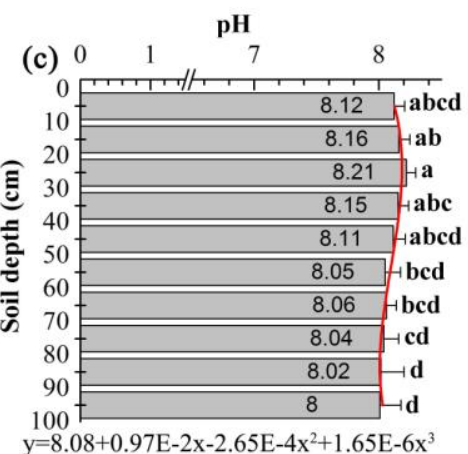

Adj. $\mathrm{R}^{2}=0.83$

\section{$\mathbf{P}\left(\mathrm{g} \mathrm{kg}^{-1}\right)$}

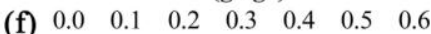

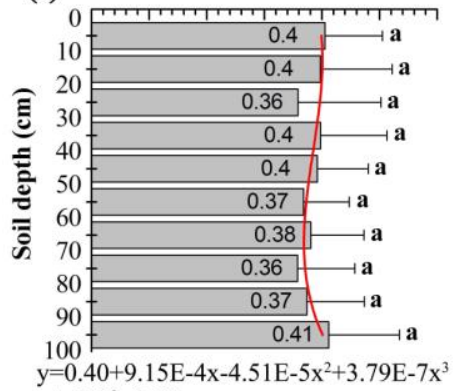

Adj. $R^{2}=0.22$

Available K $\left(\mathrm{mg} \mathrm{kg}^{-1}\right)$

(i) $\begin{array}{lllllll}0 & 20 & 40 & 60 & 80 & 100 & 120\end{array}$

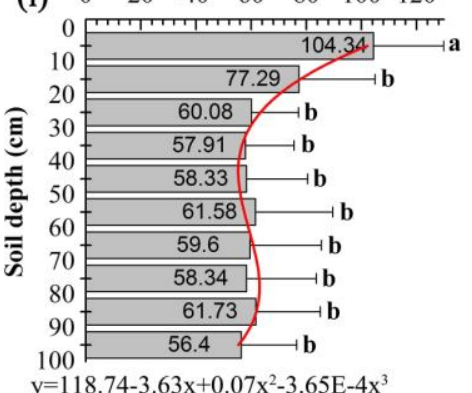

$y=118.74-3.63 x+0.07 x^{2}-3.65 E-4 x^{3}$ Adj. $R^{2}=0.94$ 
Field capacity (\%)

$\begin{array}{lllllllll}\text { (a) } & 0 & 3 & 6 & 9 & 12 & 15 & 18 & 21\end{array}$

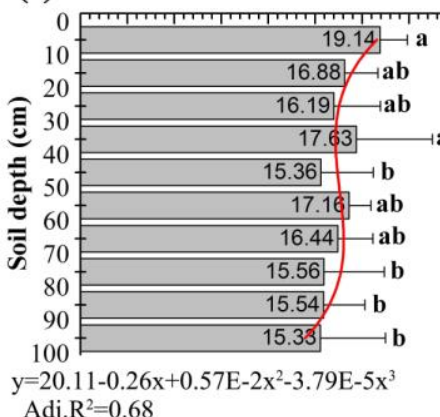

Adj. $R^{2}=0.68$

$\operatorname{SOM}\left(\mathrm{g} \mathrm{kg}^{-1}\right)$

(d) $\begin{array}{llllllll}0 & 1 & 2 & 3 & 4 & 5 & 6 & 7\end{array}$
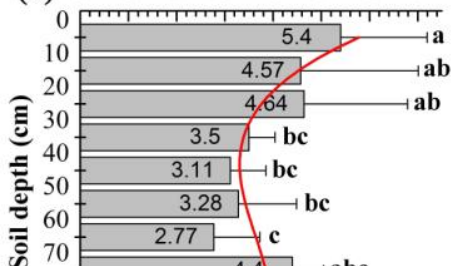

$=6.63-0.18 x+0.32 E-2 x^{2}-1.66 \mathrm{E}-5 x^{3}$ Adj. $\mathrm{R}^{2}=0.30$

$\mathrm{K}\left(\mathrm{g} \mathrm{kg}^{-1}\right)$

$\begin{array}{llllllll}\text { (g) } & 0 & 5 & 10 & 15 & 20 & 25 & 30\end{array}$

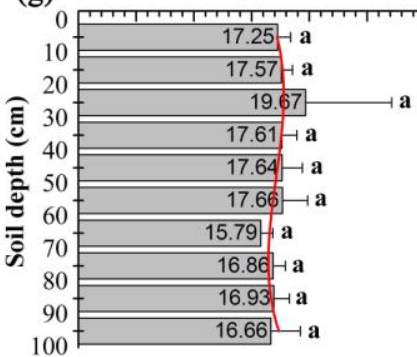

$y=16.77+0.10 x-0.29 E-2 x^{2}+2.00 E-5 x^{3}$ Adj. $R^{2}=0.32$
Bulk density $\left(\mathrm{g} \mathrm{cm}^{-3}\right)$

(b) $\begin{array}{lllllll}0.0 & 0.3 & 0.6 & 0.9 & 1.2 & 1.5 & 1.8\end{array}$

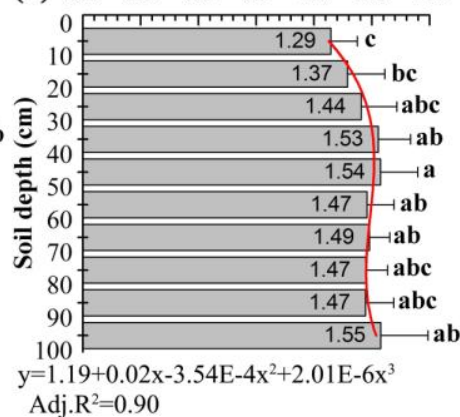

$\mathbf{N}\left(\mathrm{g} \mathrm{kg}^{-1}\right)$

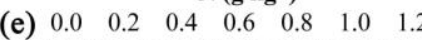

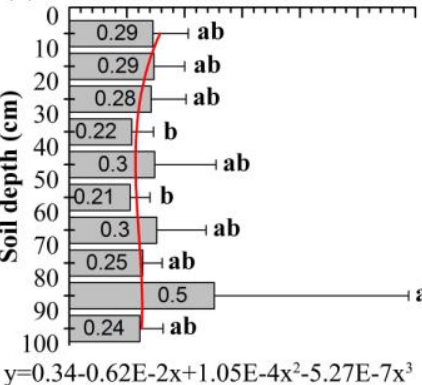

$y=0.34-0.62 E-2 x+1.05 E-4 x^{2}-5.27 E-7 x^{3}$ Adj. $R^{2}=0.07$

Available $\mathrm{P}\left(\mathrm{mg} \mathrm{kg}^{-1}\right)$

(h) $\begin{array}{llllllll}0 & 3 & 6 & 9 & 12 & 15 & 18 & 21\end{array}$

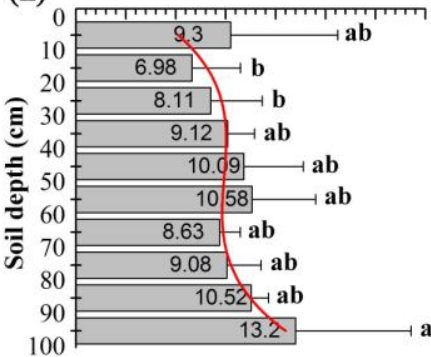

100

$y=4.88+0.28 x-0.62 E-2 x^{2}+4.31 E-5 x^{3}$ Adj. $R^{2}=0.61$

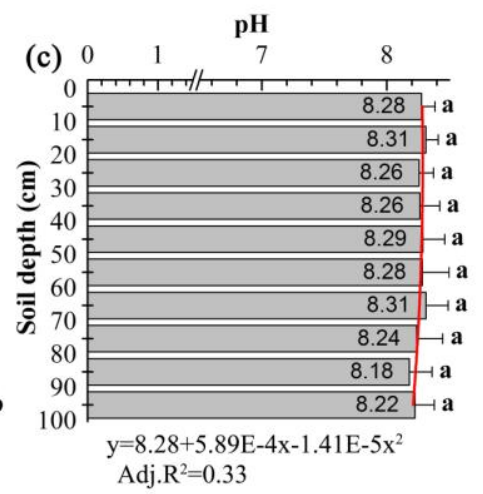

$\mathbf{P}\left(\mathrm{g} \mathrm{kg}^{-1}\right)$

(f) $\begin{array}{llllllll}0.0 & 0.1 & 0.2 & 0.3 & 0.4 & 0.5 & 0.6 & 0.7\end{array}$

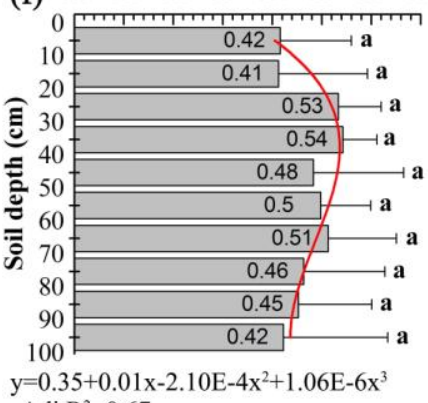
Adj. $R^{2}=0.67$

Available K ( $\mathrm{mg} \mathrm{kg}^{-1}$ )

(i) $\begin{array}{lllllll}0 & 30 & 60 & 90 & 120 & 150 & 180\end{array}$

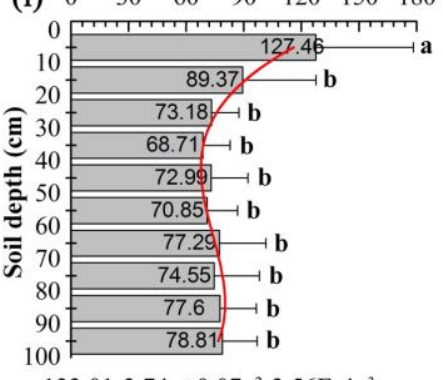

$y=133.01-3.74 x+0.07 x^{2}-3.56 E-4 x^{3}$ Adj. $R^{2}=0.78$ 

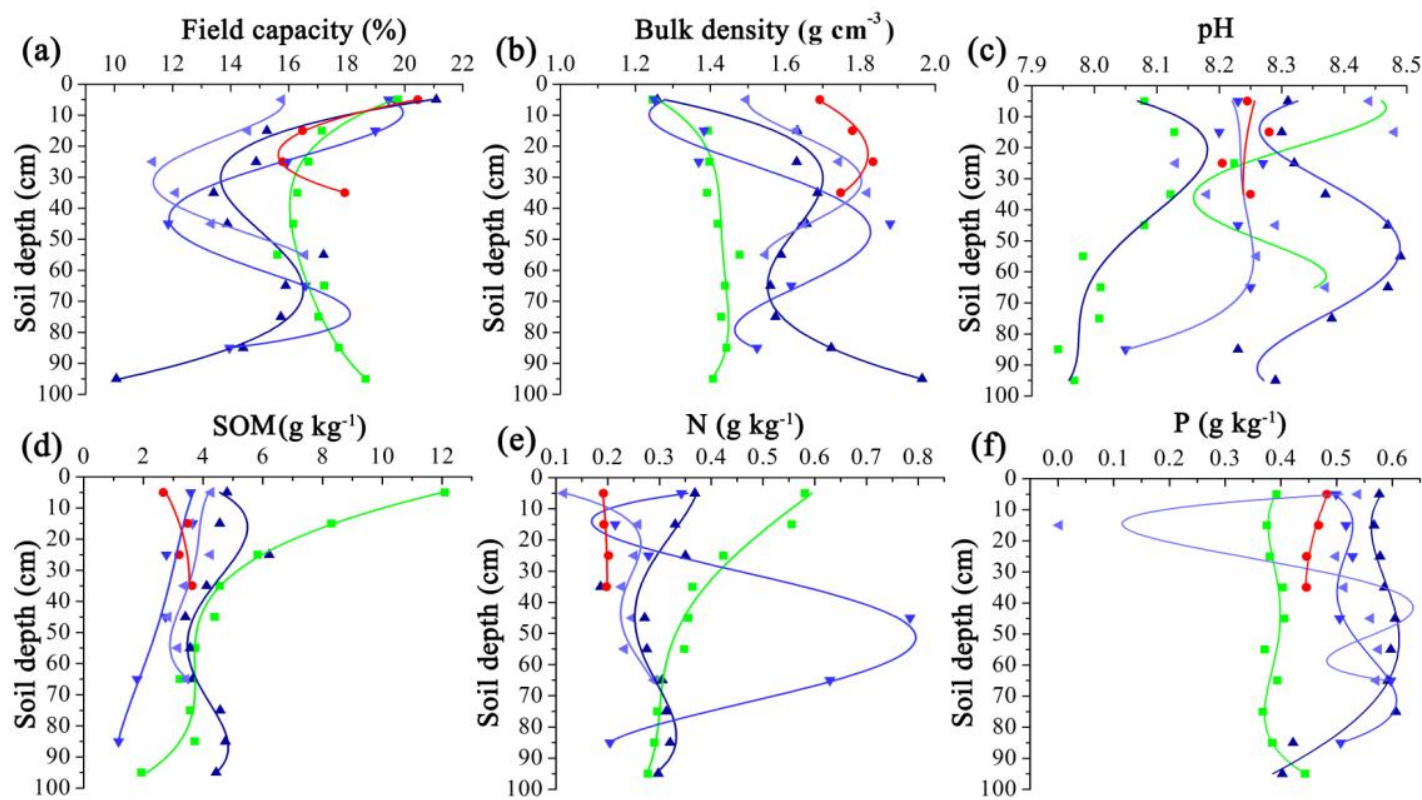

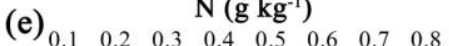
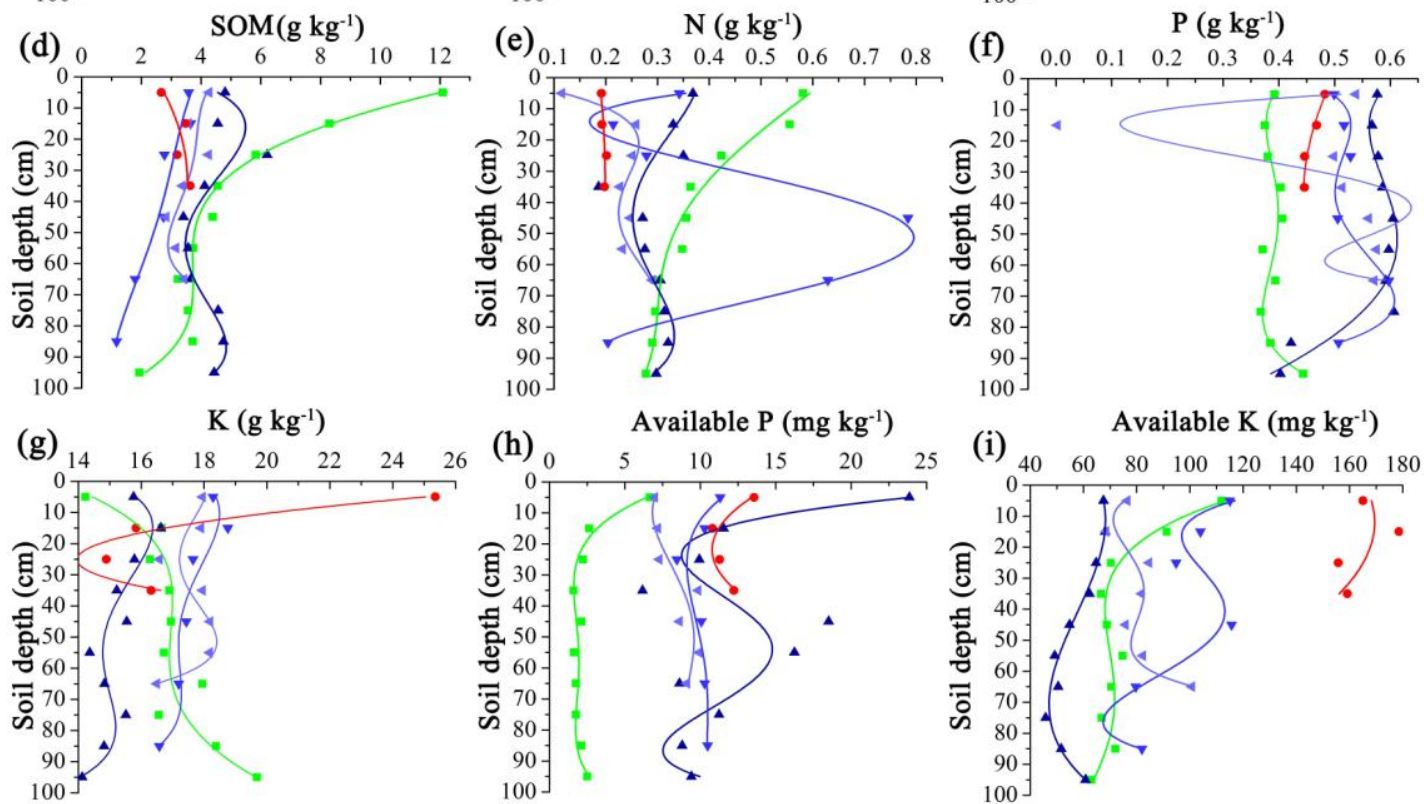

(i) Available $\mathrm{K}\left(\mathrm{mg} \mathrm{kg}^{-1}\right)$

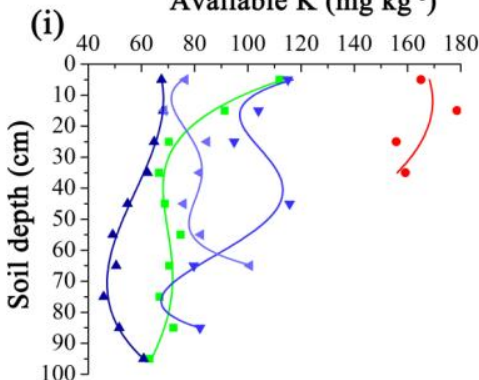

- Original site and its trendline

- 18 year-reclaimed minesoil and its trendline

$\boldsymbol{\nabla}-15$ year-reclaimed minesoil and its trendline

2 year-reclaimed minesoil and its trendline

- Unreclaimed minesoil and its trendline 

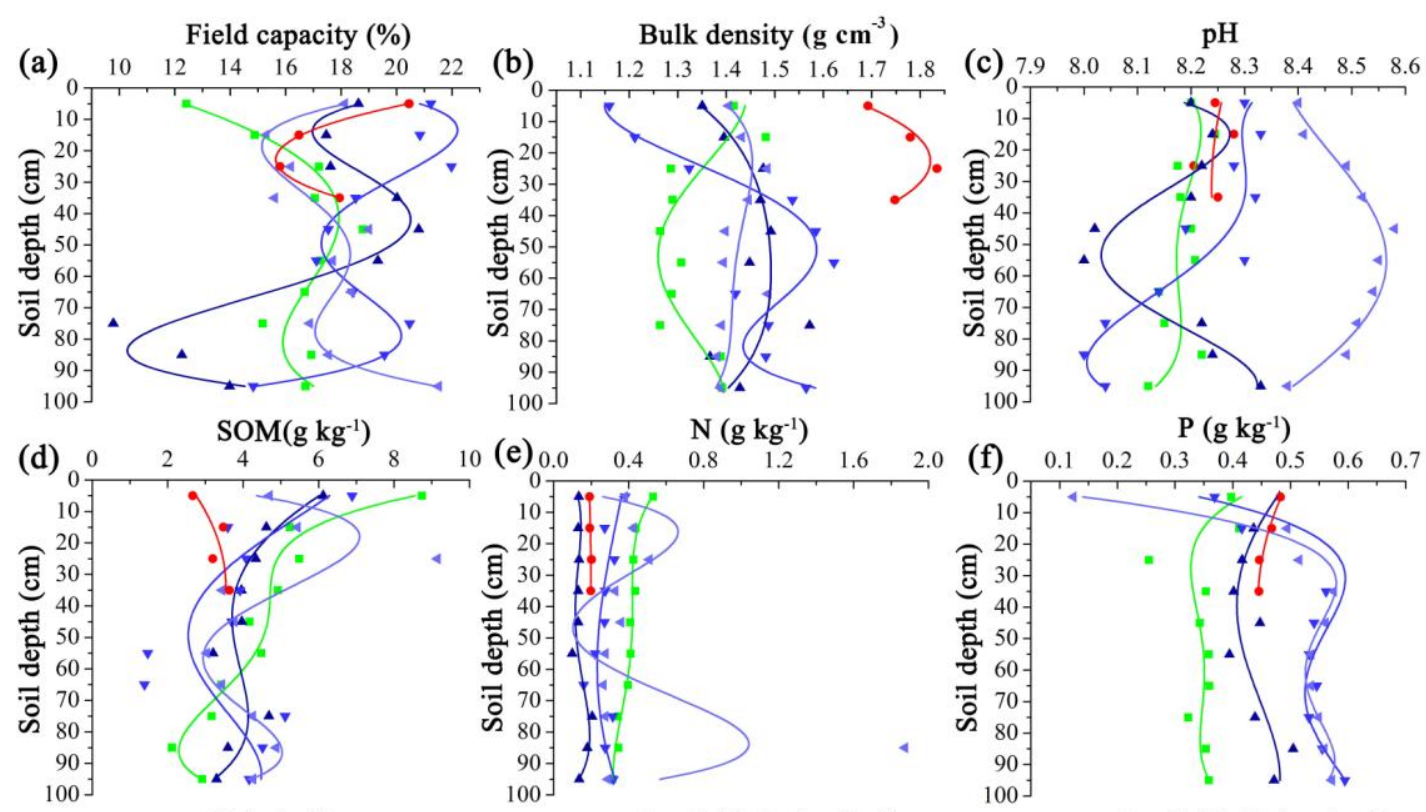

$\mathrm{P}\left(\mathrm{g} \mathrm{kg}^{-1}\right)$
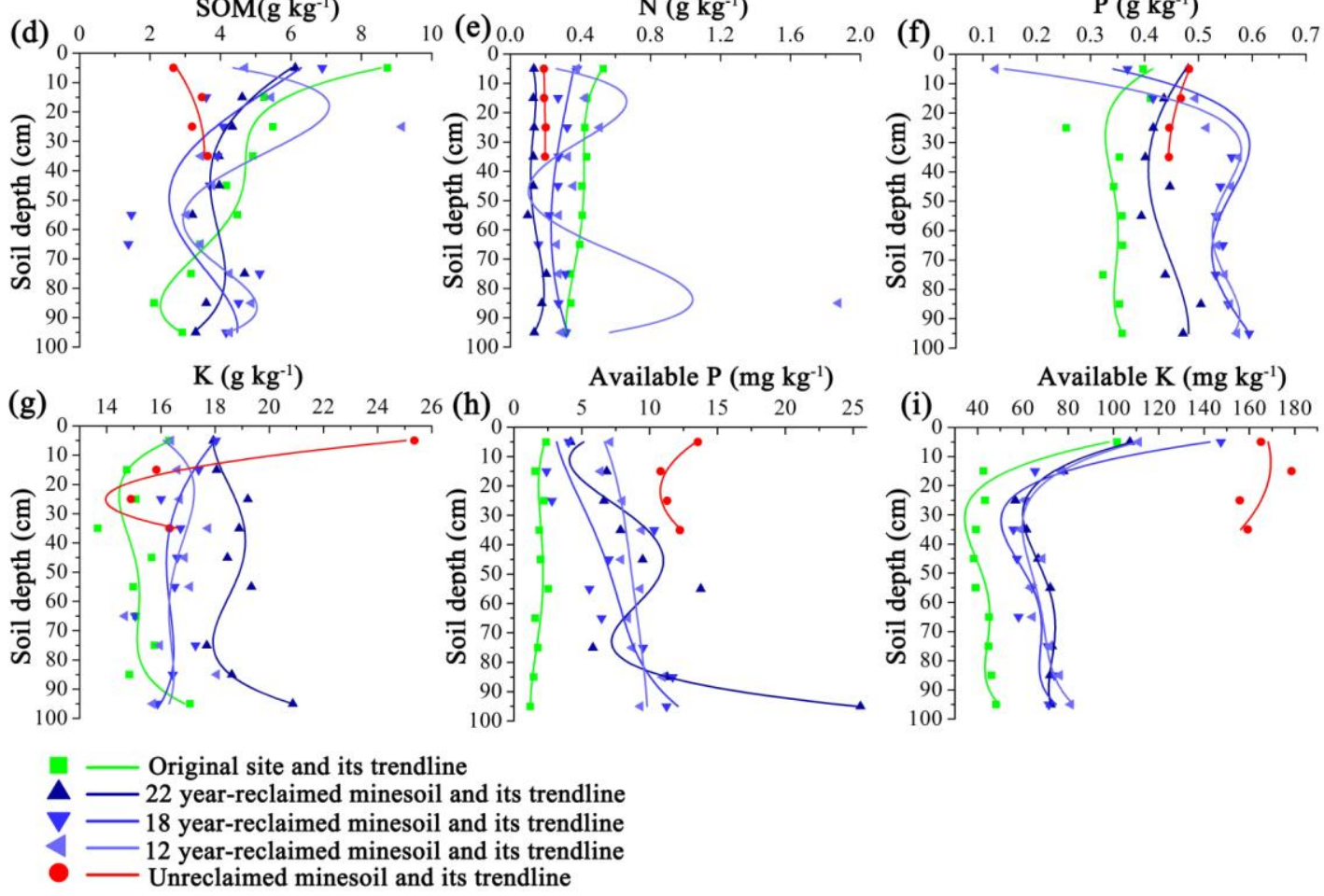

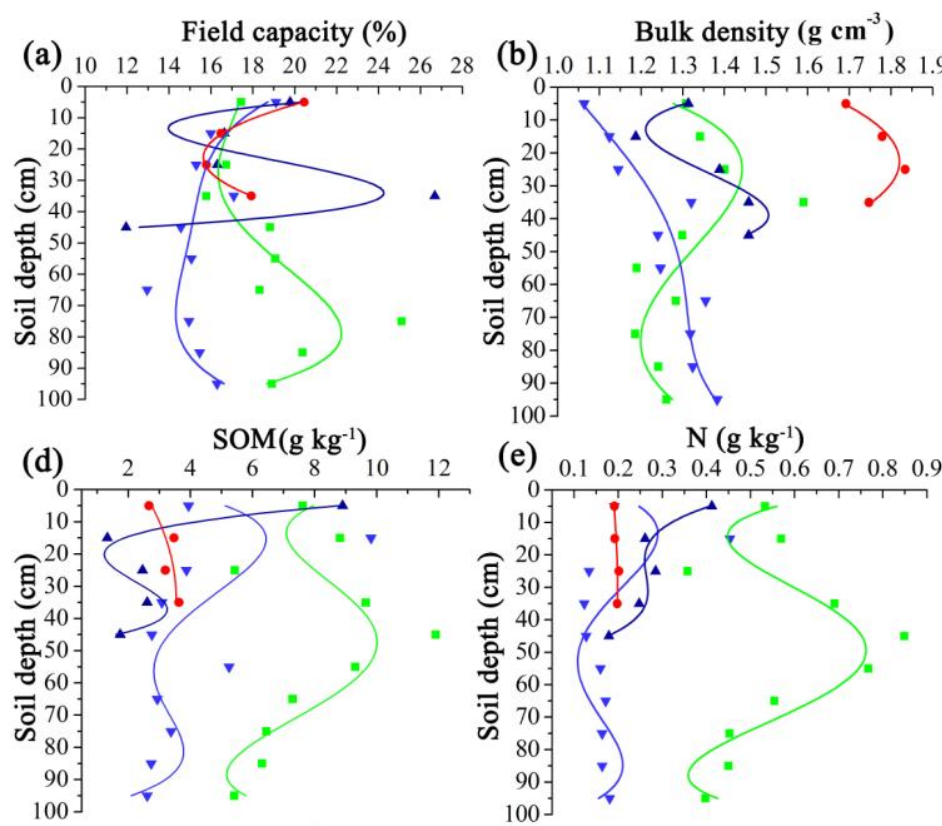

(e) $\quad \begin{aligned} & \mathrm{N}\left(\mathrm{g} \mathrm{kg}^{-1}\right) \\ & 0.10 .2\end{aligned}$
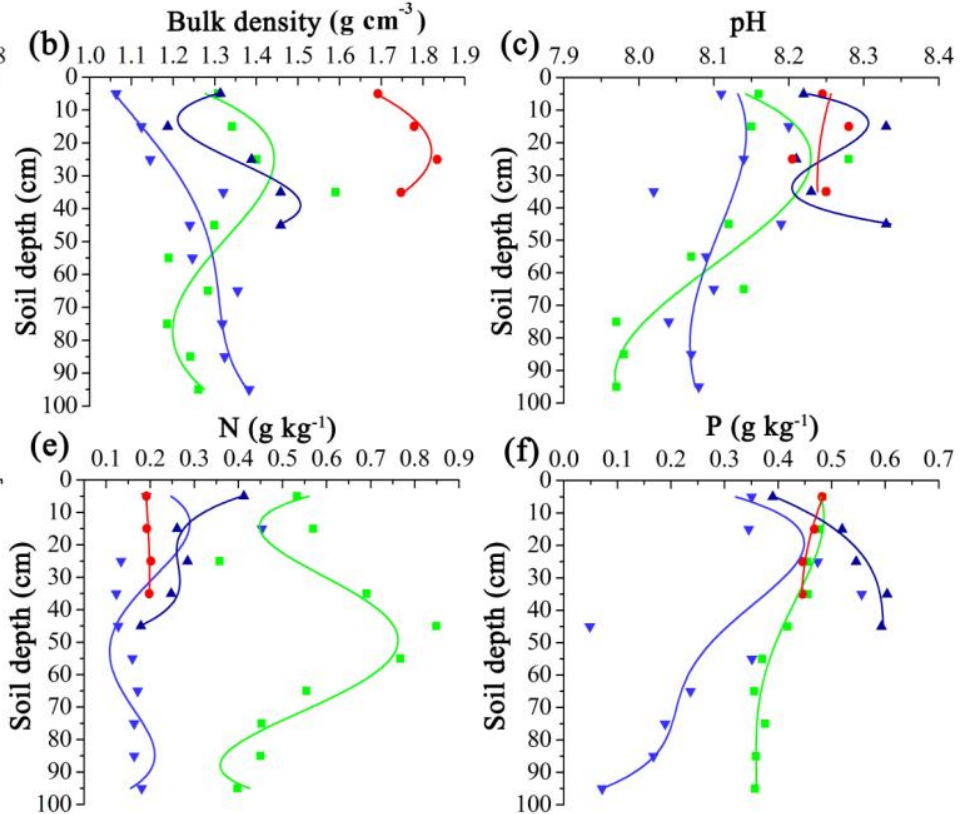

(f) $\begin{array}{llllllll}0.0 & 0.1 & 0.2 & 0.3 & 0.4 & 0.5 & 0.6 & 0.7\end{array}$
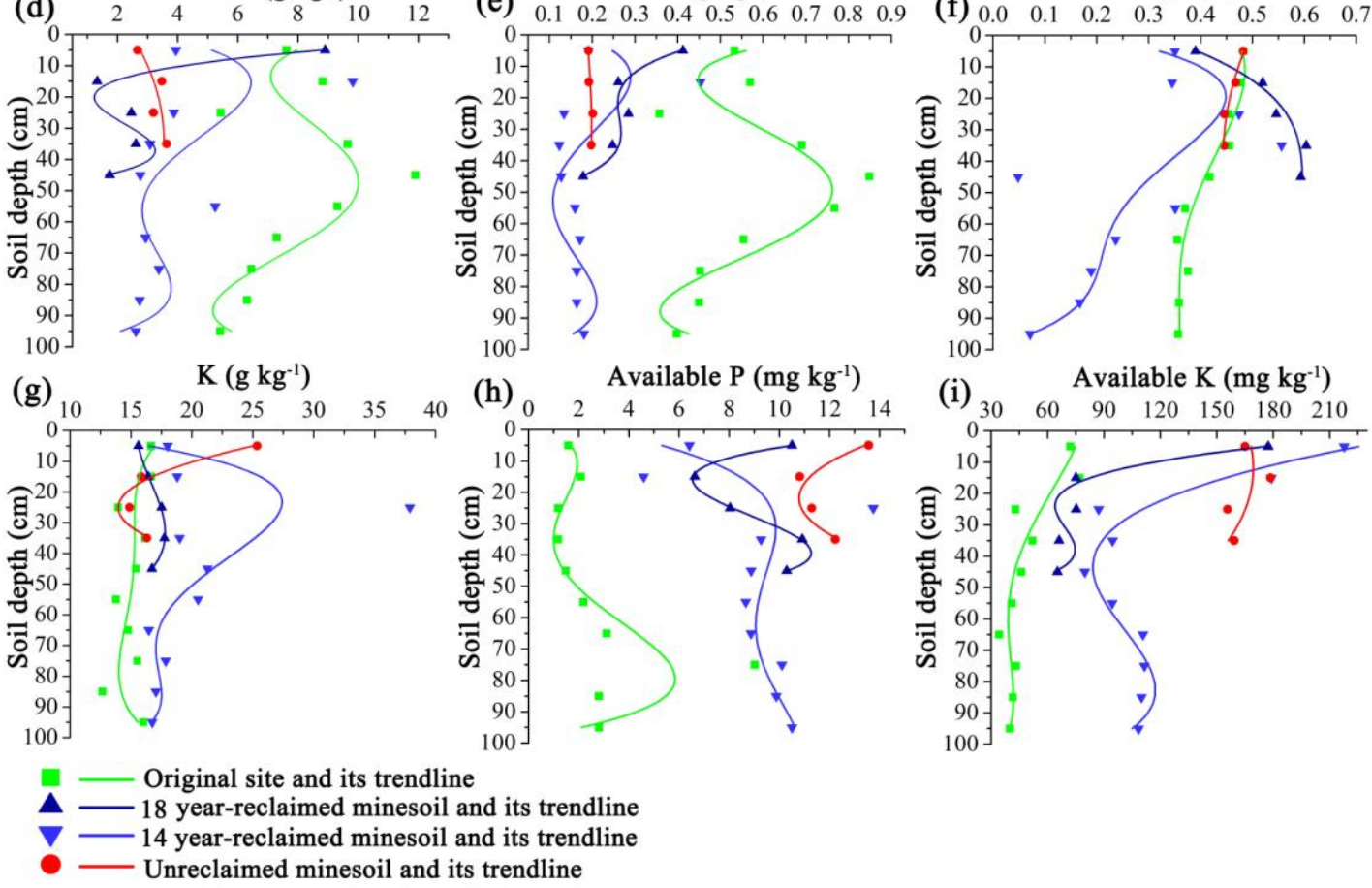

(i) Available $\mathrm{K}\left(\mathrm{mg} \mathrm{kg}^{-1}\right)$

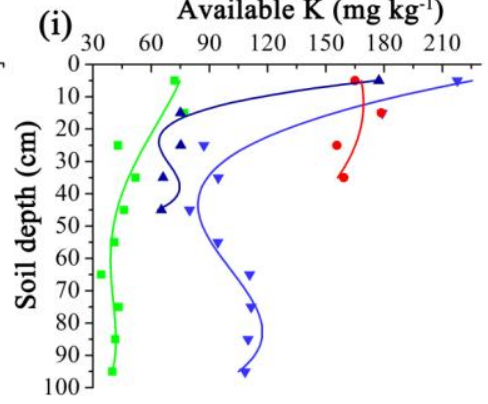


(a) Field capacity (\%)

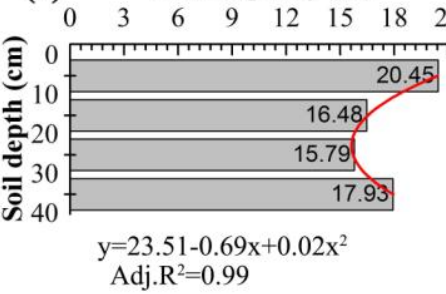

(d) $\quad \operatorname{SOM}\left(\mathrm{g} \mathrm{kg}^{-1}\right)$

$\begin{array}{llllll}0.0 & 0.8 & 1.6 & 2.4 & 3.2 & 4.0\end{array}$

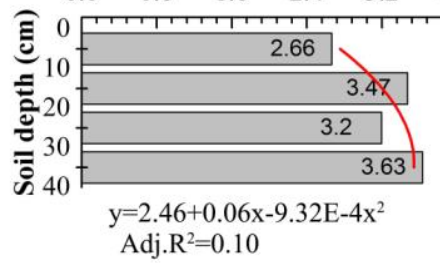

(g)

$$
\mathrm{K}\left(\mathrm{g} \mathrm{kg}^{-1}\right)
$$

$\begin{array}{llllllll}0 & 4 & 8 & 12 & 16 & 20 & 24 & 28\end{array}$

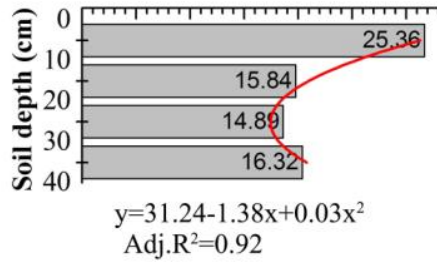

(b) Bulk density $\left(\mathrm{g} \mathrm{cm}^{-3}\right)$

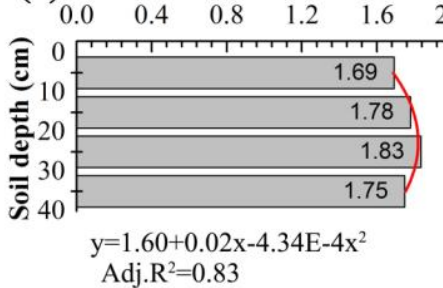

(e) $\quad \mathrm{N}\left(\mathrm{g} \mathrm{kg}^{-1}\right)$

$\begin{array}{llllll}0.00 & 0.05 & 0.10 & 0.15 & 0.20 & 0.25\end{array}$

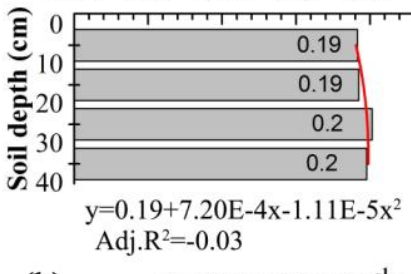

(h) Available $\mathbf{P}\left(\mathrm{mg} \mathrm{kg}^{-1}\right)$ $\begin{array}{llllllll}0 & 2 & 4 & 6 & 8 & 10 & 12 & 14\end{array}$

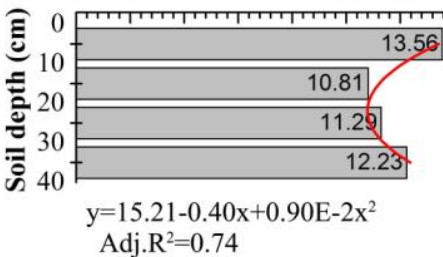

(c)

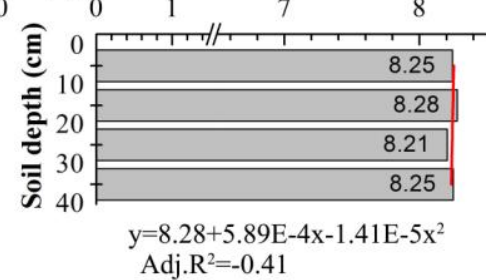

(f) $\quad \mathrm{P}\left(\mathrm{g} \mathrm{kg}^{-1}\right)$

$\begin{array}{llllll}0.0 & 0.1 & 0.2 & 0.3 & 0.4 & 0.5\end{array}$

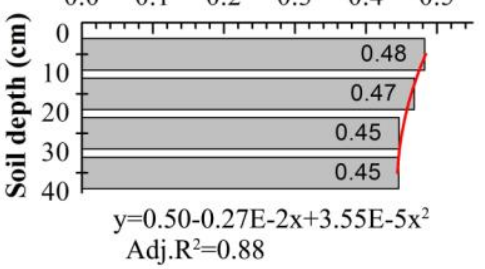

(i) Available $\mathrm{K}$ ( $\left.\mathrm{mg} \mathrm{kg}^{-1}\right)$

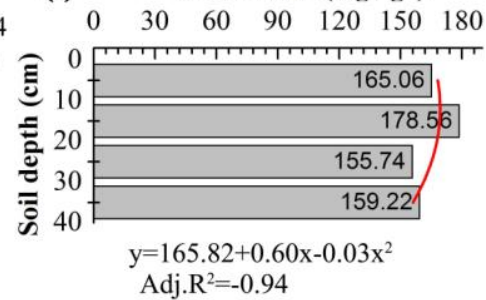

